December 2015

\title{
Specifically Authorized by Binding Precedent Does Not Mean Suggested by Persuasive Precedent: Applying Good-Faith Exception After Davis v. United States
}

\author{
Zachary C. Bolitho \\ Campbell University School of Law
}

Follow this and additional works at: https://researchrepository.wvu.edu/wvlr

Part of the Constitutional Law Commons, Fourth Amendment Commons, and the Jurisprudence Commons

\section{Recommended Citation}

Zachary C. Bolitho, Specifically Authorized by Binding Precedent Does Not Mean Suggested by Persuasive Precedent: Applying Good-Faith Exception After Davis v. United States, 118 W. Va. L. Rev. (2015).

Available at: https://researchrepository.wvu.edu/wvlr/vol118/iss2/5

This Article is brought to you for free and open access by the WVU College of Law at The Research Repository @ WVU. It has been accepted for inclusion in West Virginia Law Review by an authorized editor of The Research Repository@WVU. For more information, please contact ian.harmon@mail.wvu.edu. 


\title{
SPECIFICALLY AUTHORIZED BY BINDING PRECEDENT DOES NOT MEAN SUGGESTED BY PERSUASIVE PRECEDENT: APPLYING THE GOOD-FAITH EXCEPTION AFTER DAVIS $v$. UNITED STATES
}

\author{
Zachary C. Bolitho*
}

\begin{tabular}{|c|c|}
\hline & \\
\hline I. & INTRODUCTION............. \\
\hline & THE CURRENT STATUS \\
\hline & XCLUSIC \\
\hline & A. The Road to Davis v. United States .................... \\
\hline & B. Davis v. United States......... \\
\hline & 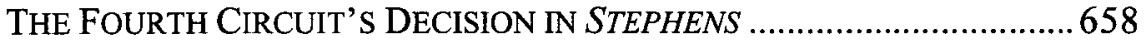 \\
\hline & A. Factual and Procedural Background .................... \\
\hline & B. The Majority Opinion . \\
\hline & 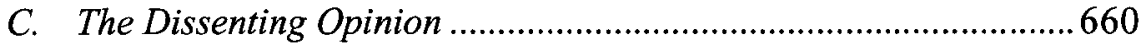 \\
\hline & ANALYSIS OF THE “KNOTTS IS BINDING PRECEDENT UNDER DAVIS” \\
\hline & APPROACH....... \\
\hline & A. Knotts Does Not Cor \\
\hline & B. A Better Path Lea \\
\hline & THE NEXT WAVE OF LITIGATION REGARDING THE SCOPE OF \\
\hline & DAVIS'S HO \\
\hline & CONCLUSION ................. \\
\hline
\end{tabular}

\section{ABSTRACT}

A number of federal circuit courts have refused to apply the Fourth Amendment's exclusionary rule to evidence obtained from GPS vehicle trackers that were installed and monitored without a warrant before United States $v$. Jones. Those courts have largely reached that result by invoking Davis $v$. United States's holding that the exclusionary rule does not apply where an officer reasonably relied on binding appellate precedent that was later overruled. More specifically, the circuit courts have viewed the Supreme Court's 1983 decision in United States v. Knotts (addressing "beeper" tracking

* Assistant Professor of Law, Campbell University School of Law and former Assistant United States Attorney for the Eastern District of Tennessee. I would like to thank Michael B. Kent, Jr., Bryan Boyd, Daniel Tilly, and Steve Cook for their helpful comments on earlier drafts of this Article. I would also like to thank Davis Puryear for his research assistance. 
devices) as binding precedent that specifically authorized the warrantless installation and monitoring of GPS vehicle trackers prior to Jones.

The Fourth Circuit's decision in United States $v$. Stephens is representative of the "Knotts is binding precedent under Davis approach" that most of the circuit courts have used to resolve the exclusionary rule question. This Article, therefore, uses Stephens as a vehicle for analyzing that approach. This Article argues that decisions like Stephens have stretched the holding of Davis and interpreted Knotts in a way that contradicts Supreme Court precedent. And, the circuit courts have done so for no good reason because they could have reached the same result-refusing to exclude the GPS vehicle tracker evidence - by working through the general good-faith analysis. Instead, most of the circuit courts have chosen to resolve the exclusionary rule issue by defining the terms "specifically authorized" and "binding precedent" to mean "suggested" and "persuasive precedent." In the process, the courts have converted the intentionally narrow holding of Davis into a broad decision with unknown boundaries.

\section{INTRODUCTION}

At first blush, the Supreme Court's holding in Davis v. United States ${ }^{1}$ seems straightforward: "We hold that searches conducted in objectively reasonable reliance on binding appellate precedent are not subject to the exclusionary rule." 2 Those words, however, have proven to be anything but straightforward. Identifying the scope of Davis's holding has generated much controversy in the lower courts ${ }^{3}$ and the legal academy. ${ }^{4}$

\footnotetext{
$1 \quad 131$ S. Ct. 2419 (2011).

2 Id. at 2423-24.

3 Compare United States v. Martin, 712 F.3d 1080, 1082 (7th Cir. 2013) (rejecting the government's good-faith argument and reading Davis narrowly), with United States v. Stephens, 764 F.3d 327, 337 (4th Cir. 2014) (adopting the government's good-faith argument and "expressing serious doubts" about the defendant's narrow interpretation of Davis), cert. denied, 2015 WL 1970174 (U.S. Oct. 5, 2015) (No. 14-1313), and United States v. Katzin, 769 F.3d 163, 177-79 (3d Cir. 2014) (en banc) (divided en banc decision accepting the government's goodfaith argument and vacating prior panel decision that rejected the good-faith argument based on a narrow reading of Davis), cert. denied, $135 \mathrm{~S}$. Ct. 1448 (2015).

$4 \quad$ See, e.g., Susan Freiwald, The Davis Good Faith Rule and Getting Answers to the Questions Jones Left Open, 14 N.C. J.L. \& TECH. 341, 357-61 (2013) (explaining the competing interpretations of Davis and arguing in favor of a narrow reading of the Court's opinion); Orin Kerr, Fourth Amendment Remedies and Development of the Law: A Comment on Camreta v. Greene and Davis v. United States, 2010-2011 CATO SuP. CT. REV. 237, 255 (discussing Davis and the future direction of the exclusionary rule); Caleb Mason, New Police Surveillance Technologies and the Good-Faith Exception: Warrantless GPS Tracker Evidence After United States v. Jones, 13 Nev. L.J. 60, 63-64 (2012) (disagreeing with Professor Tomkovicz and reading Davis as a "straightforward adoption" of the rule that reliance on binding precedent does not trigger the exclusionary rule); James J. Tomkovicz, Davis v. United States: The Exclusion
} 
Much of the controversy has occurred in cases involving the installation and subsequent monitoring of Global Positioning System ("GPS") vehicle trackers." More specifically, the courts have been grappling with whether the exclusionary rule applies to information obtained from GPS vehicle trackers that were installed and monitored before January 23, 2012the date of the Supreme Court's decision in United States v. Jones. ${ }^{6}$ The Jones Court held that a Fourth Amendment "search" occurs when police officers install and then monitor a GPS vehicle tracker. ${ }^{7}$ The Court reached that result by resuscitating a Fourth Amendment theory that most believed had been dead for decades: trespass law. ${ }^{8}$

Prior to Jones, it was widely believed that installation and monitoring of a GPS vehicle tracker did not constitute a Fourth Amendment "search," so long as the monitoring occurred only on public roadways. " That belief was grounded in two Supreme Court cases from the 1980s-United States $v$. Knotts $^{10}$ and United States v. Karo ${ }^{11}$-that dealt with location information obtained from a precursor to GPS technology colloquially referred to as a

Revolution Continues, 9 OHIO ST. J. CRIM. L. 381, 382 (2011) (arguing that Davis "confirms the advent of a new era of exclusionary rule development, reflecting the Roberts Court's commitment to a revolutionary, and stifling, revision of the Fourth Amendment bar to illegally obtained evidence").

5 See, e.g., Katzin, 769 F.3d at 168-69, 171-73 (vacating panel decision and discussing the application of Davis to cases involving the installation and monitoring of GPS vehicle trackers); United States v. Brown, 744 F.3d 474, 478 (7th Cir.) (recognizing the "legitimate debate" over the application of Davis to cases involving the installation and monitoring of GPS vehicle trackers), cert. denied 135 S. Ct. 378 (2014).

$6 \quad 132$ S. Ct. 945,949 (2012).

7 See id.

8 See id. at 949-50; see also Jordan Miller, New Age Tracking Technologies in the PostUnited States v. Jones Environment: The Need for Model Legislation, 48 CREIGHTON L. REV. $553,555-56$ (2015) (referring to the property-based rationale used by the Jones Court as an analysis that "was thought long dead").

$9 \quad$ See United States v. Katzin, 732 F.3d 187, 229 (3d Cir. 2013) (Van Antwerpen, J., dissenting) (citing cases and recognizing that there had been "a uniform consensus across the federal courts of appeals to address the issue that the installation and subsequent use of GPS or a GPS-like device was not a search or, at most, was a search but did not require a warrant"); United States v. McIver, 186 F.3d 1119, 1125-27 (9th Cir. 1999) (holding that installation and monitoring of a GPS device was not a Fourth Amendment "search"), partially abrogated by United States v. Jones, 132 S. Ct. 945 (2012), as recognized in United States v. Pineda-Moreno, 688 F.3d 1087, 1091 (9th Cir. 2012); see also United States v. Rayford, 556 F. App'x 678, 679 n.2 (10th Cir. 2014) (pointing out that prior to Jones most courts believed the police did not need a warrant to install and monitor GPS vehicle trackers); United States v. Marquez, 605 F.3d 604, 609-10 (8th Cir. 2010) (stating in dicta that the warrantless use of a GPS device to track the defendant's vehicle did not violate the Fourth Amendment).

$10 \quad 460$ U.S. $276(1983)$.

11468 U.S. 705 (1984). 
"beeper."12 Both Knotts and Karo applied the tried-and-true reasonable expectation of privacy test from Katz $v$. United States ${ }^{13}$ to determine whether a Fourth Amendment "search" occurred. ${ }^{14}$

The Jones Court's reliance on trespass law instead of the Katz reasonable expectation of privacy test was unanticipated ${ }^{15}$ and it caused considerable angst in the law enforcement community. ${ }^{16}$ That angst was understandable; at the moment Jones was decided, there were thousands of GPS vehicle trackers being monitored by police agencies nationwide. ${ }^{17}$ Very few of those were installed and monitored with judicial approval. ${ }^{18}$ Given the generally accepted belief that Knotts and Karo authorized GPS tracking on public roadways, the warrantless installation and monitoring of GPS vehicle trackers was standard police practice. ${ }^{19}$ Indeed, it was United States Department of Justice policy not to seek a warrant to monitor a GPS device on public roadways. ${ }^{20}$ So, the question raised in courtrooms nationwide in the

12 See Knotts, 460 U.S. at 277 ("A beeper is a radio transmitter, usually battery operated, which emits periodic signals that can be picked up by a radio receiver."); see also lan Herbert, Note, Where We Are with Location Tracking: A Look at the Current Technology and the Implications on Fourth Amendment Jurisprudence, 16 BERKELEY J. CRIM. L. 442, 467-76 (2011) (explaining how the "beeper" used in Knotts worked and comparing it to newer location-tracking technology, including GPS).

$$
13 \quad 389 \text { U.S. } 347 \text { (1967). }
$$

14 See Knotts, 460 U.S. at 281-82 (applying the Katz reasonable expectation of privacy test and concluding that "[a] person traveling in an automobile on public thoroughfares has no reasonable expectation of privacy in his movements from one place to another"); see also Karo, 468 U.S. at 712-15 (applying the Katz test and distinguishing Knotts because the beeper in Karo was monitored while inside of a home, a place (unlike the public roadways) where the defendant had a reasonable expectation of privacy).

15 See Jace C. Gatewood, It's Raining Katz and Jones: The Implications of United States v. Jones-A Case of Sound and Fury, 33 PACE L. REV. 683, 690 (2013) (explaining that "many were left utterly shocked by the Court's almost total rejection" of Katz, Knotts, and Karo "in favor of a doctrine that most believed was dead-the "trespass doctrine"').

16 See Carrie Johnson, FBI Still Struggling with Supreme Court's GPS Ruling, NPR (Mar. 21, 2012), http://www.npr.org/2012/03/21/149011887/fbi-still-struggling-with-supreme-courtsgps-ruling (reporting that "Jones set off alarm bells inside the FBI, where officials are trying to figure out whether they need to change the way they do business").

17 See Transcript of Oral Argument, United States v. Jones, 132 S. Ct. 945 (2012) (No. $10-$ 1259), $2011 \mathrm{WL} 5360051$, at *59 (estimating that federal law enforcement agencies annually installed GPS devices "in the low thousands").

18 See Johnson, supra note 16.

19 See generally United States v. Stephens, 764 F.3d 327, 331 (4th Cir. 2014) (reporting that the officer who installed the GPS vehicle tracker at issue "had attached a GPS to other vehicles in public areas without a warrant, and it was his understanding that a warrant was needed only when ... the GPS was wired into the vehicle's battery system"), cert. denied, 2015 WL 1970174 (U.S. Oct. 5, 2015) (No. 14-1313).

20 See United States v. Katzin, 769 F.3d 163, 181 (3d Cir. 2014) (en banc) (reporting that prior to Jones, the Department of Justice policy was "that a warrant was not required to install a 
wake of Jones was (and continues to be) as follows: Does the exclusionary rule apply to evidence obtained from GPS vehicle trackers that were installed and monitored without a warrant before Jones?

In seeking to answer that question, the courts have run head-on into Davis's holding that the exclusionary rule does not apply where officers relied in good faith on binding precedent that was later overruled. The question has now been considered by almost all of the federal circuit courts ${ }^{21}$ and a handful of state appellate courts. ${ }^{22}$ The vast majority of the courts have refused to apply the exclusionary rule on the basis that the officers who installed and monitored the GPS vehicle trackers pre-Jones acted in good faith. With the exception of the Sixth and Ninth Circuits, ${ }^{23}$ the federal appellate courts have reached that conclusion by holding that the Supreme Court's decision regarding "beepers" in Knotts (or a circuit court decision authorizing the use of "beepers") qualified under Davis as binding precedent specifically authorizing the installation and monitoring of GPS vehicle trackers. ${ }^{24}$ Those courts have endorsed a broad

battery-powered GPS on a vehicle parked on a public street and to surveil it on public roads"), cert. denied, 135 S. Ct. 1448 (2015).

21 See, e.g., United States v. Robinson, 781 F.3d 453 (8th Cir. 2015); United States v. Katzin, 769 F.3d 163 (3d Cir. 2014) (en banc), cert. denied, 135 S. Ct. 1448 (2015); United States v. Fisher, 745 F.3d 200 (6th Cir.), cert. denied, 135 S. Ct. 676 (2014); United States v. Brown, 744 F.3d 474 (7th Cir.), cert. denied, 135 S. Ct. 378 (2014); United States v. Aguiar, 737 F.3d 251 (2d Cir. 2013), cert. denied, 135 S. Ct. 400 (2014); United States v. Barraza-Maldonado, 732 F.3d 865 (8th Cir. 2013); United States v. Sparks, 711 F.3d 58 (1st Cir.), cert. denied, 134 S. Ct. 204 (2013); United States v. Andres, 703 F.3d 828 (5th Cir.), cert. denied, 133 S. Ct. 2814 (2013); United States v. Smith, 741 F.3d 1211 (11th Cir. 2013), cert. denied, 135 S. Ct. 704 (2014); United States v. Pineda-Moreno, 688 F.3d 1087 (9th Cir. 2012), cert. denied, 133 S. Ct. 994 (2013).

22 See, e.g., State v. Mitchell, 323 P.3d 69 (Ariz. Ct. App. 2014); People v. LeFlore, 32 N.E.3d 1043 (Ill. 2015); Kelly v. State, 56 A.3d 523 (Md. Ct. Spec. App. 2012); State v. Johnson, 22 N.E.3d 1061 (Ohio 2014); State v. Adams, 763 S.E.2d 341 (S.C. 2014).

${ }^{23}$ The Ninth Circuit had a prior published decision that specifically authorized the warrantless installation and monitoring of GPS vehicle trackers. See United States v. Mclver, 186 F.3d 1119, 1126-27 (9th Cir. 1999), partially abrogated by United States v. Jones, 132 S. Ct. 945 (2012), as recognized in United States v. Pineda-Moreno, 688 F.3d 1087, 1091 (9th Cir. 2012). The Ninth Circuit relied on its prior decision in McIver to conclude that the exclusionary rule was inappropriate under Davis because the installation and monitoring of the GPS vehicle tracker complied with binding circuit court precedent that was later overruled. See Pineda-Moreno, 688 F.3d at 1090 (refusing to apply the exclusionary rule under Davis because prior "circuit precedent held that placing an electronic tracking device on the undercarriage of a car was neither a search nor a seizure under the Fourth Amendment"). Similarly, the Sixth Circuit relied on one of its prior decisions in Fisher to conclude that precedent provided binding authority permitting the police to use the GPS tracker. Fisher, 745 F.3d at 203 (discussing United States v. Forest, 355 F.3d 942, 951-52 (6th Cir. 2004)).

24 See, e.g., United States v. Katzin, 769 F.3d 163 (3d Cir. 2014) (en banc), cert. denied, 135 S. Ct. 1448 (2015); United States v. Stephens, 764 F.3d 327 (4th Cir. 2014), cert. denied, 2015 WL 1970174 (U.S. Oct. 5, 2015) (No. 14-1313); United States v. Fisher, 745 F.3d 200 (6th Cir.), cert. denied, 135 S. Ct. 676 (2014); United States v. Brown, 744 F.3d 474 (7th Cir.), cert. denied, 
reading of Davis and have rejected the defendants' claims that Davis only applies in the rare circumstance where there is a prior published decision from the governing circuit court that directly addresses the precise issue raised in the current case. $^{25}$

The Fourth Circuit's 2-1 decision in United States v. Stephens ${ }^{26}$ is representative of the "Knotts is binding precedent under Davis approach." The Stephens majority and the dissent fully addressed the arguments on both sides; therefore, Stephens is an excellent vehicle for discussing and analyzing the applicability of Davis to the pre-Jones installation and monitoring of GPS vehicle trackers. The Stephens majority-like many of its sister circuitsscoffed at the defendant's narrow interpretation of Davis and held that the exclusionary rule did not apply to evidence obtained from a GPS vehicle tracker that was installed and monitored without a warrant. ${ }^{27}$ Although the Stephens majority admitted there was no binding Fourth Circuit precedent specifically authorizing the warrantless installation and monitoring of GPS vehicle trackers, the Court opined that "a reasonably well-trained officer in this Circuit could have relied on [the Supreme Court's decision in] Knotts as permitting" such conduct. ${ }^{28}$ Similar reasoning can be found in opinions from the First, Second, Third, Fifth, Seventh, Eighth, and Eleventh Circuits. ${ }^{29}$

Judge Stephanie Thacker sharply disagreed with the Stephens majority. She argued in her dissent that the holding of Davis was a "specific and narrow" one that required "binding appellate precedent specifically authorizing" the warrantless installation and monitoring of GPS vehicle trackers. ${ }^{30}$ Because there was no such precedent in the Fourth Circuit, Judge Thacker would have concluded that Davis's good-faith rationale did not apply. ${ }^{31}$ Judge Thacker's dissent mirrored the approach of the five judges who dissented from the Third Circuit's en banc determination that Knotts qualified as binding precedent

135 S. Ct. 378 (2014); United States v. Sparks, 711 F.3d 58 (1st Cir.), cert. denied, 134 S. Ct. 204 (2013); United States v. Aguiar, 737 F.3d 251 (2d Cir. 2013), cert. denied, 135 S. Ct. 400 (2014); United States v. Andres, 703 F.3d 828 (5th Cir.), cert. denied, 133 S. Ct. 2814 (2013); United States v. Smith, 741 F.3d 1211 (11th Cir. 2013), cert. denied, 135 S. Ct. 704 (2014); United States v. Barraza-Maldonado, 732 F.3d 865 (8th Cir. 2013).

25 See, e.g., Katzin, 769 F.3d at 176 ("Undoubtedly, certain language in Davis invites a narrow reading, but we are not persuaded this interpretation is true to Davis'[s] holding.").

26764 F.3d 327 (4th Cir. 2014), cert. denied, 2015 WL 1970174 (U.S. Oct. 5, 2015) (No. 141313).

$27 \quad$ See id. at $337-38$.

28 See id. at 338.

29 See, e.g., Katzin, 769 F.3d 163; Brown, 744 F.3d 474; Sparks, 711 F.3d 58; Aguiar, 737 F.3d 251; Andres, 703 F.3d 828; Barraza-Maldonado, 732 F.3d 865; Smith, 741 F.3d 1211.

30 Stephens, 764 F.3d at 341 (Thacker, J., dissenting).

31 Id. at $341-42$. 
under Davis. ${ }^{32}$ Several state appellate courts have also echoed Judge Thacker's thoughts on the issue. ${ }^{33}$

This Article examines the "Knotts is binding precedent under Davis approach" and explains why such an approach is inconsistent with Supreme Court precedent. This Article also argues that the circuit courts should have resolved cases like Stephens by applying the general "good-faith" analysis. Part II discusses the Fourth Amendment exclusionary rule with a particular focus on the good-faith exception. Part III provides a brief summary of the majority and dissenting opinions from the Fourth Circuit's decision in Stephens. Part IV analyzes the "Knotts is binding precedent under Davis approach" that has been adopted by Stephens and most other circuit courts. It argues that a better approach would have been for the courts to resolve the exclusionary rule issue by simply applying the general good-faith analysis. Part $\mathrm{V}$ considers how the broad reading of Davis that underlies the "Knotts is binding precedent under Davis approach" will play out in future cases, such as those involving the application of the exclusionary rule to cell phone searches conducted before the Supreme Court's recent watershed decision in Riley $v$. California. ${ }^{34}$ A brief conclusion follows in Part VI.

32 See Katzin, 769 F.3d at 187-97 (Greenaway, J., dissenting). Judge Greenaway was the author of the Third Circuit's panel decision, which applied the exclusionary rule and found that Knotts did not qualify as binding appellate precedent under Davis. Id. The en banc Third Circuit vacated the panel decision and held eight to five that the evidence was saved from suppression by the good-faith exception to the exclusionary rule. $I d$. ("[W]e conclude that the good faith exception applies, and that suppression is unwarranted.').

33 See, e.g., State v. Mitchell, 323 P.3d 69, 78 (Ariz. Ct. App. 2014) (concluding that Knotts was "not sufficiently apposite on the trespass question and, therefore, cannot trigger application of the good-faith exception" under Davis v. United States); State v. Hohn, 321 P.3d 799 (Kan. Ct. App. 2014) (unpublished table decision) (holding that it "was clearly unreasonable for the State to have read Karo and Knotts as authorizing the warrantless installation of a [GPS] tracking device" on the defendant's car); State v. Adams, 763 S.E.2d 341, 346-47 (S.C. 2014) (applying the exclusionary rule and concluding that "Knotts and Karo did not constitute binding precedent that authorized law enforcement's warrantless" installation and monitoring of a GPS vehicle tracker).

34134 S. Ct. 2473, 2480 (2014). The Court in Riley held that police officers must obtain a warrant before searching a cell phone, even if the cell phone was found on the defendant's person at the time of his lawful arrest. Id. at 2485 . In reaching that conclusion, the Court carved out an exception to the search incident to lawful arrest doctrine-a doctrine that allows police officers who make a lawful arrest to conduct a warrantless search of the arrestee's person, including containers found on the arrestee's person. Id. at 2483-84. 


\section{THE CURRENT STATUS OF THE FOURTH AMENDMENT EXCLUSIONARY RULE}

The Fourth Amendment exclusionary rule has long been controversial. ${ }^{35}$ And, the rule's development has been anything but smooth. Indeed, Justice Potter Stewart once referred to the exclusionary rule as "a bit jerry-built-like a roller coaster track constructed while the roller coaster sped along." ${ }^{, 36}$ In the years since its creation in 1914, the exclusionary rule has certainly taken many twists and turns. Perhaps the most significant twists and turns have occurred in the last decade-a time period during which the Supreme Court issued a number of important decisions regarding the exclusionary rule's scope. The following sections explain the current status of the exclusionary rule and describe the road the Court took to get there.

\section{A. The Road to Davis v. United States}

The exclusionary rule, generally speaking, prevents the prosecution from introducing evidence that has been obtained in violation of the Fourth Amendment. ${ }^{37}$ Although the general rule is easy enough to recite, its precise scope has been the source of ongoing debate and continual change. ${ }^{38}$ That has been especially true in the last nine years as the Supreme Court has handed down three important decisions: Hudson v. Michigan, ${ }^{39}$ Herring v. United States, ${ }^{40}$ and Davis v. United States. ${ }^{41}$ Depending on who one believes, those three decisions have either dramatically modified the exclusionary rule ${ }^{42}$ or have simply returned the exclusionary rule to its original moorings. ${ }^{43}$

35 See Elkins v. United States, 364 U.S. 206, 216 (1960) (discussing the development of the exclusionary rule and stating that the rule "has for decades been the subject of ardent controversy").

36 Potter Stewart, The Road to Mapp v. Ohio and Beyond: The Origins, Development and Future of the Exclnsionary [sic] Rule in Search-and-Seiznre [sic] Cases, 83 COLUM. L. REV. 1365,1366 (1983).

37 See Illinois v. Krull, 480 U.S. 340, 347 (1987) ("When evidence is obtained in violation of the Fourth Amendment, the judicially developed exclusionary rule usually precludes its use in a criminal proceeding against the victim of the illegal search and seizure.").

38 See Tomkovicz, supra note 4, at 384-94 (discussing how the exclusionary rule has evolved with time); see also Andrew Guthrie Ferguson, Constitutional Culpability: Questioning the New Exclusionary Rules, 66 FLA. L. REv. 623, 624 (2014) (opining that the "Supreme Court has recently directed a sustained legal assault against the exclusionary rule").

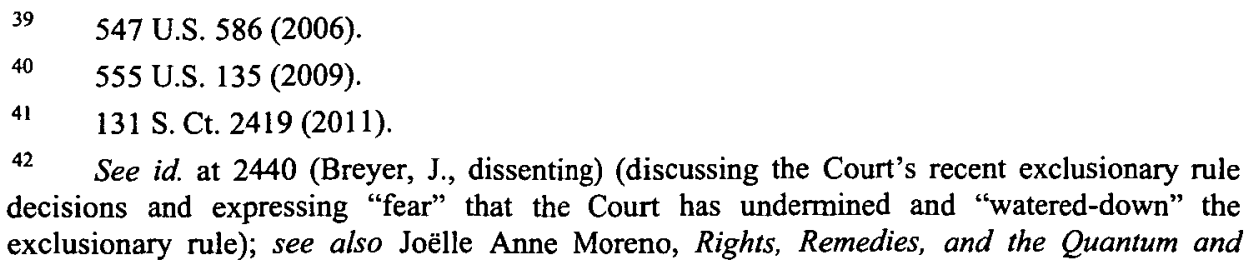


First recognized by the Supreme Court in $1914^{44}$ and incorporated to the states through the Fourteenth Amendment in $1961,{ }^{45}$ the exclusionary rule is nowhere to be found in the text of the Fourth Amendment. ${ }^{46}$ It is a judicially created remedy that was initially viewed as serving two purposes: (1) deterring unconstitutional police conduct ${ }^{47}$ and (2) maintaining judicial integrity. ${ }^{48}$ For a period of time after its creation, the exclusionary rule was viewed as "a selfexecuting" constitutional mandate that required no further analysis. ${ }^{49}$ If there was a Fourth Amendment violation, then the evidence was automatically excluded. ${ }^{50}$ That began to change over time, however, as the Court recognized numerous exceptions.

Burden of Proof, 3 VA. J. CRIM. L. 89, 164 (2015) (stating that through cases like Herring and Davis, the Supreme Court has "clearly changed the suppression landscape").

43 See Hudson, 547 U.S. at 591 (insisting that the exclusionary rule "has always been our last resort, not our first impulse," while recognizing that over the years some opinions "did not always speak so guardedly").

44 See Weeks v. United States, 232 U.S. 383, 398 (1914) ("We therefore reach the conclusion that the letters in question were taken from the house of the accused by an official of the United States, acting under color of his office, in direct violation of the constitutional rights of the defendant; that having made a seasonable application for their return, which was heard and passed upon by the court, there was involved in the order refusing the application a denial of the constitutional rights of the accused, and that the court should have restored these letters to the accused. In holding them and permitting their use upon the trial, we think prejudicial error was committed."), overruled by Mapp v. Ohio, 367 U.S. 643 (1961).

45 See Mapp, 367 U.S. at 655 ("Since the Fourth Amendment's right of privacy has been declared enforceable against the States through the Due Process Clause of the Fourteenth, it is enforceable against them by the same sanction of exclusion as is used against the Federal Government."); see also Wayne R. LaFave, The Smell of Herring: A Critique of the Supreme Court's Latest Assault on the Exclusionary Rule, 99 J. CRIM. L. \& CRIMINOLOGY 757, 757 (2009) (explaining that "the Supreme Court in Mapp v. Ohio gave full effect to the Fourth Amendment by extending the suppression remedy of Weeks $v$. United States to cases in the state courts as well").

46 See Herring v. United States, 555 U.S. 135, 139 (2009) ("The Fourth Amendment... "contains no provision expressly precluding the use of evidence obtained in violation of its commands."' (quoting Arizona v. Evans, 514 U.S. 1, 10 (1995))); see also Mapp, 367 U.S. at 661 (Black, J., concurring) (recognizing that "the Fourth Amendment does not itself contain any provision expressly precluding the use of [unconstitutionally obtained] evidence").

47 Mapp, 367 U.S. at 656 (stating that the "purpose of the exclusionary rule 'is to deter- to compel respect for the constitutional guaranty in the only effectively available way-by removing the incentive to disregard it" (quoting Elkins v. United States, 364 U.S. 206, 217 (1960))).

48 Id. at 659 (explaining that "there is another consideration-the imperative of judicial integrity" (quoting Elkins, 364 U.S. at 217)).

49 Davis v. United States, 131 S. Ct. 2419, 2427 (2011).

50 See Ferguson, supra note 38 , at 625 (explaining that the exclusionary rule was "once an automatic remedy for constitutional violations"). 
Those exceptions include the independent source doctrine, ${ }^{51}$ the inevitable discovery doctrine, ${ }^{52}$ the attenuation doctrine, ${ }^{53}$ and-of particular importance to the current discussion-the good-faith exception. ${ }^{54}$ The goodfaith exception was announced in United States $v$. Leon. ${ }^{55}$ In Leon, the Court refused to apply the exclusionary rule where an officer reasonably relied on a magistrate's issuance of a warrant that was later found to be invalid. ${ }^{56}$ The rationale of Leon was applied in Illinois $v$. Krull to prevent the exclusion of evidence where an officer reasonably relied on a legislative enactment later determined to be unconstitutional. ${ }^{57}$ It was also applied in Arizona v. Evans to prevent the exclusion of evidence where an officer reasonably relied on courtmanaged databases later found to be inaccurate. ${ }^{58}$ Leon, Krull, and Evans all shared one key attribute-the good-faith reliance of a police officer on an erroneous act by either the judicial or legislative branches of government. ${ }^{59}$ At the time they were announced, the exceptions were exactly that-exceptions. The general rule for evidence obtained in connection with a violation of the Fourth Amendment remained exclusion.

That paradigm began to shift dramatically in 2006 when the Court announced its decision in Hudson v. Michigan. ${ }^{60}$ Justice Scalia, writing for the Hudson majority, refused to apply the exclusionary rule where officers violated

51 See Murray v. United States, 487 U.S. 533 (1988) (holding that evidence originally discovered illegally may be admitted if such evidence was also later discovered in a manner that was independent of the initial illegality).

$52 \quad$ See Nix v. Williams, 467 U.S. 431, 432 (1984) (holding that evidence obtained from an illegal search may be admitted if the government proves by a preponderance of the evidence that the evidence would have "ultimately or inevitably . . . been discovered by lawful means").

53 See Wong Sun v. United States, 371 U.S. 471, 471 (1963) (holding that illegally discovered evidence may be admitted if the connection between the illegal search and the evidence has "become so attenuated as to dissipate the taint" (quoting Nardone v. United States, 308 U.S. 338, 341 (1939))).

$54 \quad$ See United States v. Leon, 468 U.S. 897 (1984).

$55 \quad I d$. at $908-09$.

$56 \quad$ Id. at 913.

57 See Illinois v. Krull, 480 U.S. 340 (1987).

58 See Arizona v. Evans, 514 U.S. 1, 9-16 (1995).

59 See Matthew Allan Josephson, To Exclude or Not To Exclude: The Future of the Exclusionary Rule After Herring v. United States, 43 CREIGHTON L. REV. 175, 181 (2009) (explaining that before Herring, the Court "only applied the 'good faith' exception to the Fourth Amendment exclusionary rule in situations where police acted in reasonable reliance on a judicial or legislative representation that authorized the police conduct").

60547 U.S. 586 (2006); see Chris Blair, Hudson v. Michigan: The Supreme Court Knocks and Announces the Demise of the Exclusionary Rule, 42 TULSA L. REV. 751, 755 (2007) (stating that the Court in Hudson "fundamentally altered the traditional application of the exclusionary rule"). 
the Fourth Amendment's knock and announce requirement. ${ }^{61}$ Hudson ushered in a new era of Fourth Amendment law-an era where the exclusionary rule is the judiciary's "last resort, not our first impulse." 62 While the Court recognized that some of its prior cases did not "speak so guardedly" about the exclusionary rule, Hudson explained that evidence should only be excluded when the deterrent value of exclusion exceeds the "substantial social costs" of letting guilty people go free. ${ }^{63}$ Whereas the exclusionary rule was initially viewed as serving the dual purposes of deterrence and the maintenance of judicial integrity, Hudson not so covertly signaled that deterrence was the principal rationale going forward. ${ }^{64}$

The signal from Hudson became a command three years later in Herring $\nu$. United States. ${ }^{65}$ The specific holding in Herring was that the goodfaith exception applied to an officer's objectively reasonable reliance on a law enforcement database that was later found to be inaccurate. ${ }^{66}$ The Court's holding was significant because it extended the good-faith exception to an error committed by a law enforcement entity, as opposed to another branch of government. ${ }^{67}$ But, Herring is less important for what it specifically held than for the broad doctrine-changing language that is littered throughout the opinion. ${ }^{68}$

\footnotetext{
61

See Hudson, 547 U.S. at 594.

62 Id. at 591; see Ferguson, supra note 38, at 631 (writing that prior to Hudson "Supreme Court opinions assumed with little difficulty an intrinsic link between the exclusionary rule and unconstitutional action, without any separation of rights and remedies"); see also Blair, supra note 60, at 760 ("The decision in Hudson has now made it possible to so finely delineate the interests protected by various parts of the Fourth Amendment that the exclusionary rule sanction will not be an appropriate remedy for some constitutional violations.").

$63 \quad$ Hudson, 547 U.S. at 591, 596 (quoting United States v. Leon, 468 U.S. 897, 907 (1984)).

$64 \quad$ Id. at $596,599$.

65555 U.S. 135, 137 (2009).

$66 \quad I d$.

67 See Josephson, supra note 59, at 181; see also Claire Angelique Nolasco, Rolando V. del Carmen \& Michael S. Vaughn, What Herring Hath Wrought: An Analysis of Post-Herring Cases in the Federal Courts, 38 AM. J. CRIM. L. 221, 227 (2011) (explaining that prior to Herring, the good-faith exception case law "did not address whether the exclusionary rule applied to illegal searches made by law enforcement officers in good-faith reliance on mistakes made by other law enforcement employees").

68 See Tomkovicz, supra note 4, at 390 (stating that the "Herring majority... was not content merely to resolve this narrow issue," opting instead to speak "quite broadly" about the exclusionary rule); see also LaFave, supra note 45, at 758 (criticizing Herring and speculating on how the Court's decision will alter the application of the exclusionary rule going forward); see also Tracey Maclin \& Jennifer Rader, No More Chipping Away: The Roberts Court Uses an Axe to Take Out the Fourth Amendment Exclusionary Rule, 81 Miss. L.J. 1183, 1203-04 (2012) (stating that Herring contained "big blast" language that signaled the Court's intent to "restrict the exclusionary rule to instances of culpable police behavior").
} 
The Herring Court made clear that the exclusionary rule is a remedy that must be analyzed separately from the determination of whether there was a constitutional violation. ${ }^{69}$ In the words of the Court, "that a search or arrest was unreasonable-does not necessarily mean that the exclusionary rule applies." 70 Rather, the exclusionary rule only applies if the officer's conduct was "deliberate, reckless, ... grossly negligent" or the result of "recurring or systemic negligence."71 The language and tone of Herring has led some scholars to declare that the exclusionary rule is now best understood as less of a "rule" and more of an exception that only applies when the deterrent value of suppression outweighs the societal cost of excluding highly probative evidence of guilt. ${ }^{72}$ The Herring Court focused entirely on "deterrence and culpability" with not a mention of Mapp $v$. Ohio's judicial integrity rationale. ${ }^{73}$ In a passage that would prove important two years later in Davis, the Court reiterated that the good-faith exception saves evidence from suppression if, under the circumstances, "a reasonably well trained officer" would have believed the search was lawful. ${ }^{74}$

See Herring, 555 U.S. at 137 (pointing out that "suppression is not an automatic consequence of a Fourth Amendment violation"); see also Heien v. North Carolina, $135 \mathrm{~S}$. Ct. 530,544 (2014) (Sotomayor, J., dissenting) (disagreeing with the majority's conclusion that an officer does not violate the Fourth Amendment by making a reasonable mistake of law, and pointing out that the better approach would be to handle the officer's reasonable mistake of law at the "remedial" step because "[o]ur jurisprudence draws a sharp 'analytica[1] distinct[ion]' between the existence of a Fourth Amendment violation and the remedy for that violation" (quoting Davis v. United States, $131 \mathrm{~S}$. Ct. 2419, 2431 (2011))); see also Ferguson, supra note 38, at 625 (explaining that Herring represents "new territory for lawyers and courts accustomed to an automatic linkage between constitutional wrongs and constitutional remedies").

70

Herring, 555 U.S. at 140.

71 Id.

72 See Josephson, supra note 59, at 176-77 (characterizing Herring as a "landmark criminal procedure opinion" that "could transform the exclusionary rule by making the exclusion of evidence the exception rather than the rule"); see also Maclin \& Rader, supra note 68, at 1208 (explaining that "[i]f under Herring, only culpable or deliberate violations of the Fourth Amendment merit suppression, then a great number-perhaps the overwhelming majority-of unreasonable searches and seizures will be immunized from the exclusionary rule").

73 See Herring, 555 U.S. at 141 ("The principal cost of applying the rule is, of course, letting guilty and possibly dangerous defendants go free-something that 'offends basic concepts of the criminal justice system."' (quoting United States v. Leon, 468 U.S. 897, 908 (1984))); see also $i d$. at 147 (explaining that "the deterrent effect of suppression must be substantial and outweigh any harm to the justice system").

74 See id. at 145 (citing Leon, 468 U.S. at 922, for the proposition that "our good-faith inquiry is confined to the objectively ascertainable question whether a reasonably well trained officer would have known that the search was illegal in light of all the circumstances"). 


\section{B. Davis v. United States}

In 2011, the Court released its much-anticipated opinion in Davis v. United States. ${ }^{75}$ The precise question before the Court was whether the exclusionary rule should apply to searches conducted in reliance on binding precedent that was later overruled. ${ }^{76}$ To understand the Court's conclusion and reasoning, a brief overview of the factual and procedural history of the case is in order.

During the course of a routine traffic stop in 2007, local police officers in Alabama arrested Willie Davis (a passenger in the car) for lying about his identity. ${ }^{77}$ The officers handcuffed Davis and secured him in the backseat of a police cruiser. ${ }^{78}$ The officers then searched the passenger compartment of the car where they found a handgun in Davis's jacket. ${ }^{79}$ Davis - a convicted felon-was charged with being a felon in possession of a firearm, in violation of 18 U.S.C. $\S 922(\mathrm{~g}){ }^{80}$ Prior to trial, he moved to suppress the gun on the ground that it was found during a warrantless search that was unsupported by probable cause. ${ }^{81}$

The trial court gave Davis's argument short shrift. ${ }^{82}$ After all, it was well settled that the Supreme Court's 1981 decision in New York v. Belton ${ }^{83}$ authorized police officers to search a car's passenger compartment without a warrant or probable cause so long as there was a lawful arrest of a recent occupant. $^{84}$ Indeed, the Eleventh Circuit (and every other circuit for that matter) had specifically upheld searches in cases with facts nearly identical to those in

\footnotetext{
$75 \quad 131$ S. Ct. 2419 (2011).

76 Id. at 2423 ("The question here is whether to apply [the exclusionary rule] when the police conduct a search in compliance with binding precedent that is later overruled.").

$77 \quad$ Id. at 2425 .

$78 \quad$ Id.

79 Id.

80 Id. at 2425-26.

$81 \quad$ Id.

82 Id. at 2426 (pointing out that at the district court level Davis conceded that his argument was foreclosed by binding precedent).

83453 U.S. 454 (1981), abrogated by Davis, 131 S. Ct. 2419. The Belton Court held that when an officer lawfully arrests the occupant of an automobile he may, as a contemporaneous incident of that arrest, search without a warrant or probable cause the passenger compartment of the automobile and any containers found therein. Id. at 460-61.

84 See United States v. Katzin, 769 F.3d 163, 172 (3d Cir. 2014) (en banc) ("It was widely understood that the Court [in Belton] had issued a bright-line rule, and that vehicle searches incident to the arrest of recent occupants were reasonable, regardless of whether the arrestee "was within reaching distance of the vehicle at the time of the search."'), cert. denied, 135 S. Ct. 1448 (2015).
} 
Davis. ${ }^{85}$ As Davis's appeal was grinding its way through the system, however, the Supreme Court did an about-face with its 2009 decision in Arizona v. Gant. ${ }^{86}$ The Gant Court held that officers may only search a car incident to a lawful arrest of a recent occupant if: (1) the arrestee is unsecured and within the grabbing area of the car during the search; or (2) there is reason to believe that evidence related to the crime of arrest will be found in the car. ${ }^{87}$

In light of Gant, the Eleventh Circuit found in Davis that the officers violated the Fourth Amendment when they searched the car. ${ }^{88}$ But the Eleventh Circuit refused to exclude the gun because the officers relied in good faith on prior binding precedent that specifically authorized the search. ${ }^{89}$ The Supreme Court granted certiorari and affirmed in an opinion by Justice Alito. ${ }^{90}$

Picking up where Herring left off, the Davis Court reinforced the notion that the exclusionary rule is a punitive device that should only be used in response to police conduct that was "deliberate enough to yield 'meaningful' deterrence, and culpable enough to be "worth the price paid by the justice system." ${ }^{\prime 91}$ Reasoning that an officer who follows binding precedent should be faulted no more than an officer who follows a magistrate judge's probable cause determination (Leon), ${ }^{92}$ a legislative enactment (Krull), ${ }^{93}$ a court

85 See, e.g., United States v. Gonzalez, 71 F.3d 819, 822, 824-27 (11th Cir. 1996) (finding no Fourth Amendment violation where officers searched the defendant's car incident to his lawful arrest after he was handcuffed and secured away from the car); see also Davis, $131 \mathrm{~S}$. Ct. at 2424 (recognizing that "Belton was widely understood to have set down a simple, bright-line rule ... authoriz[ing] automobile searches incident to arrests of recent occupants, regardless of whether the arrestee in any particular case was within reaching distance of the vehicle at the time of the search").

$86 \quad 556$ U.S. 332 (2009).

87 Id. at $342-43$.

88 United States v. Davis, 598 F.3d 1259, 1263 (11th Cir. 2010), aff'd, Davis, 131 S. Ct. 2419 ("There can be no serious dispute that the search here violated Davis's Fourth Amendment rights as defined in Gant.").

89 Id. at 1264 ("We now enter the fray and hold that the exclusionary rule does not apply when the police conduct a search in objectively reasonable reliance on our well-settled precedent, even if that precedent is subsequently overruled.").

90 Davis, 131 S. Ct. 2419. Justice Alito's opinion was joined by Chief Justice Roberts and Justices Scalia, Kennedy, Thomas, and Kagan. Id. at 2423. Justice Sotomayor concurred in the judgment. $I d$. at 2434 . Justice Breyer authored a dissenting opinion that was joined by Justice Ginsburg. Id. at 2436.

91 Id. at 2428 (quoting Herring v. United States, 555 U.S. 135, 144 (2009)).

92 United States v. Leon, 468 U.S. 897, 922 (1984) ("We conclude that the marginal or nonexistent benefits produced by suppressing evidence obtained in objectively reasonable reliance on a subsequently invalidated search warrant cannot justify the substantial costs of exclusion.").

$93 \quad$ Illinois v. Krull, 480 U.S. 340,349 (1987) ("The application of the exclusionary rule to suppress evidence obtained by an officer acting in objectively reasonable reliance on a statute 
computer database (Evans), ${ }^{94}$ or a law enforcement database (Herring), ${ }^{95}$ the Court concluded that "evidence obtained during a search conducted in reasonable reliance on binding precedent is not subject to the exclusionary rule." ${ }^{.96}$ In her solo concurrence, Justice Sotomayor opined that the Court's decision should not be read as addressing the "markedly different question" of whether the exclusionary rule applies when the law is in flux and there is no binding appellate precedent specifically authorizing the officer's conduct. ${ }^{97}$

That "markedly different question" is one of many left unanswered by the Court's holding in Davis. ${ }^{98}$ Clearly, the exclusionary rule does not apply when an officer conducts a search that was specifically authorized by a prior published opinion from the governing federal circuit court. But how close do the facts of the current case and the prior case need to be in order for the officer's conduct to be specifically authorized by the prior case? ${ }^{99}$ What if a court opinion suggests that the officer's search would be permitted, "or leaves a bunch of clues, without definitively resolving the question?"100 Does Davis apply if the governing circuit court has not addressed a particular issue, but the overwhelming weight of authority from the other circuits supports the officer's conduct? ${ }^{101}$ These are the difficult questions that have confronted the circuit courts, including the Fourth Circuit in Stephens. And, the approach the Fourth

would have as little deterrent effect on the officer's actions as would the exclusion of evidence when an officer acts in objectively reasonable reliance on a warrant.").

94 Arizona v. Evans, 514 U.S. 1, 15-16 (1995) ("There is no indication that the arresting officer was not acting objectively reasonably when he relied upon the police computer record. Application of the Leon framework supports a categorical exception to the exclusionary rule for clerical errors of court employees.").

95 Herring, 555 U.S. at 147-48 ("[W]e conclude that when police mistakes are the result of negligence such as that described here, rather than systemic error or reckless disregard of constitutional requirements, any marginal deterrence [achieved by application of the exclusionary rule] does not "pay its way.").

$96 \quad$ Davis, 131 S. Ct. at 2429.

97 Id. at 2435 (Sotomayor, J., concurring).

98 See Mason, supra note 4, at 67-72 (discussing some of the questions raised by the Court's decision in Davis).

99 See Kerr, supra note 4, at 255 n.78 (noting that "[e]xactly what counts as 'binding' precedent [under Davis] can be unclear"); see also Orin Kerr, Lower Court Interpretations of Davis v. United States, 131 S. Ct. 2419 (2011), VoloKH ConsPIRACY (Aug. 14, 2013, 3:49 PM), http://volokh.com/2013/08/14/lower-court-interpretations-of-davis-v-united-states-131-s-ct-

2419-2011/ [hereinafter Lower Court Interpretations of Davis] (posing questions about the scope of Davis's holding).

$100 \quad$ See Lower Court Interpretations of Davis, supra note 99.

101 See id,; see also Freiwald, supra note 4, at 365-66 (discussing whether Davis applies where there is persuasive authority from other circuits but no binding authority in the circuit where the search occurred); Mason, supra note 4, at 72-79 (analyzing how Davis could be potentially applied in a host of different scenarios). 
Circuit took to answer the questions is representative of the approach the other circuits have taken. ${ }^{102}$

\section{THE FOURTH CIRCUIT'S DECISION IN STEPHENS}

\section{A. Factual and Procedural Background}

The case against Henry Stephens began in 2011 when a federal drug taskforce suspected he was violating drug and firearms laws. ${ }^{103}$ As part of the investigation, on May 13, 2011, a Baltimore police officer installed a GPS vehicle tracker underneath Stephens's car while it was in a public parking lot. ${ }^{104}$ The officer, who had been deputized as a federal taskforce officer, did not have a search warrant. ${ }^{105}$ Using the information provided by the GPS device, officers later located Stephens and his car outside of a nightclub where he worked as a security guard. ${ }^{106}$ A search of Stephens's car led to the discovery of a handgun. ${ }^{107}$ Because Stephens had a prior felony conviction, he was charged with being a felon in possession of a firearm. ${ }^{108}$

As Stephens awaited trial, the Supreme Court held in Jones that the installation and monitoring of a GPS vehicle tracker constituted a Fourth Amendment "search," even if the monitoring occurred on public roads. ${ }^{109}$ Stephens promptly filed a motion to suppress based on Jones. ${ }^{110}$ The district court found that Jones rendered the installation and monitoring of the GPS

102 See People v. LeFlore, 32 N.E.3d 1043, 1048 (Ill. 2015) (citing cases and reporting that "all of the federal circuits that have considered post-Jones whether the good-faith exception applies in cases of warrantless GPS searches conducted pre-Jones have rejected a narrow reading of Davis and have instead concluded that the good-faith exception applies").

103 United States v. Stephens, 764 F.3d 327, 329 (4th Cir. 2014), cert. denied, 2015 WL 1970174 (U.S. Oct. 5, 2015) (No. 14-1313).

$104 \quad I d$.

105 Id. It is a common practice for federal law enforcement agencies, such as the Drug Enforcement Administration (DEA), to form taskforces that involve state and local officers working in tandem with their federal counterparts. See generally DEA Programs: State \& Local Task Forces, DRUG ENFORCEMENT ADMIN., http://www.dea.gov/ops/taskforces.shtml (last visited Oct. 5, 2015). The state and local officers who serve on federal taskforces are deputized and given the power to perform the same general duties as full-time federal law enforcement officers. Id.

$$
\begin{array}{ll}
106 & \text { Stephens, } 764 \text { F.3d at } 330 . \\
107 & \text { Id. } \\
108 & \text { Id. } \\
109 & \text { Id. }
\end{array}
$$

110 Id. Stephens moved to suppress the location information obtained from the GPS vehicle tracker. Id. He also sought suppression of the handgun on the theory that the handgun was a fruit of the location information illegally obtained from the GPS vehicle tracker. $I d$. 
vehicle tracker on Stephens's car unconstitutional. ${ }^{111}$ Nonetheless, the district court applied the good-faith exception and refused to suppress the evidence. ${ }^{112}$ Stephens appealed, and a divided panel of the Fourth Circuit affirmed. ${ }^{113}$

\section{B. The Majority Opinion}

The Fourth Circuit majority initially framed the question presented as "whether a reasonably well trained officer would have known" that it was unconstitutional to install and monitor a GPS tracking device without a warrant. ${ }^{114}$ The Court answered that question in the negative and affirmed the district court's refusal to suppress the evidence. ${ }^{115}$ The majority acknowledged that when the officer installed the GPS vehicle tracker on Stephens's car, there was no Supreme Court or Fourth Circuit precedent specifically holding that GPS vehicle trackers could be installed and monitored without a warrant. ${ }^{116}$ This absence of binding precedent specifically authorizing GPS vehicle trackers, Stephens argued, placed the case beyond the scope of Davis's holding. ${ }^{117}$ Under Stephens's interpretation of Davis, the good-faith exception did not apply where an officer relied on "nonbinding precedent, no matter how extensive and well-developed that precedent may be." 118

Although skeptical of Stephens's narrow interpretation of Davis, the Fourth Circuit found it unnecessary to resolve whether the good-faith exception applies to an officer's reliance on nonbinding precedent because the court concluded that binding precedent, namely the Supreme Court's decision in

\footnotetext{
$111 \quad I d$.

$112 \quad$ Id.

113 Judge Shedd authored the majority opinion, which Judge Hamilton joined. Id. at 329. Judge Thacker dissented. Id.

$114 \quad$ Id

115 Interestingly, the first paragraph of the Fourth Circuit's opinion contains a significant typographical error. The court began by posing the question: "whether a reasonably well trained officer would have known that the search was illegal in light of all of the circumstances." Id. The court went on to say that "the answer to this question is 'yes.' Therefore, the exclusionary rule does not apply, and we affirm ...." Id. Indeed, if the court's answer to the question it posed was actually "yes," then the result would have been the application of the exclusionary rule and reversal. It is clear, however, from reading the opinion that the answer to the question posed was "no," and the appearance of "yes" in the opinion was a typographical error.

$116 \quad$ Id. at 332.

117 Id. at $336-37$.

118 Id. at 337. This, of course, was the question Justice Sotomayor raised in her Davis concurrence. See Davis v. United States, 131 S. Ct. 2419, 2435 (2011) (Sotomayor, J., concurring) ("This case does not present the markedly different question whether the exclusionary rule applies when the law governing the constitutionality of a particular search is unsettled.").
} 
Knotts, authorized the officer's conduct. ${ }^{119}$ The Stephens majority recognized that Knotts dealt with beepers and not GPS devices and was, therefore, not identical to the current case. ${ }^{120}$ But the court concluded that the factual differences between the two cases were insignificant given Knotts's broad proclamation that "a person traveling in an automobile on public thoroughfares has no reasonable expectation of privacy in his movements from one place to another." ${ }^{121}$ From the majority's perspective, Knotts could reasonably have been read to cover GPS vehicle trackers. ${ }^{122}$

Indeed, before Jones, several other courts had specifically held that Knotts applied to GPS vehicle trackers. ${ }^{123}$ Included among those courts was the Maryland Court of Special Appeals. ${ }^{124}$ That fact was significant to the Fourth Circuit majority because the GPS vehicle tracker was installed on Stephens's car in Maryland by a local police officer who happened to also be deputized as a federal taskforce officer. ${ }^{125}$ The language of Knotts itself and the general preJones consensus by courts led the majority to conclude that the good-faith exception prevented suppression of the evidence. ${ }^{126}$

\section{The Dissenting Opinion}

Judge Thacker advanced three primary points in her vigorous dissent. First, she argued that Davis was inapplicable because "no 'binding appellate precedent' existed in this circuit 'specifically authorizing' law enforcement's actions." ${ }^{27}$ To Judge Thacker, Davis required published precedent from the governing circuit court addressing the same legal issue in the same factual circumstances. In her opinion, Knotts was not binding appellate precedent because it did not involve the unauthorized physical attachment of a GPS device to a suspect's property. ${ }^{128}$ Additionally, Judge Thacker was concerned about the significant technological differences between the beeper in Knotts

\footnotetext{
119 Stephens, 764 F.3d at 337.

$120 \quad I d$.

121 Id. (quoting United States v. Knotts, 460 U.S. 276, 281 (1983)).

$122 \quad I d$ at 333.

123 Id. (citing cases).

$124 I$ Id. at 334 (citing Stone v. State, 941 A.2d 1238 (Md. Ct. Spec. App. 2008)).

125 See id. at 338 (" $[\mathrm{W}] \mathrm{e}$ would make a mockery of the good-faith inquiry if we were to ignore the clear pre-Jones state of the law in Maryland-as pronounced by Maryland's highest court-and hold that a Maryland officer's use of the GPS was objectively unreasonable.").

$126 \quad$ Id. at $338-39$.

127 Id. at 342 (Thacker, J., dissenting) (quoting Davis v. United States, 131 S. Ct. 2419, 2429, $2434(2011))$.

$128 \quad I d$.
} 
and the GPS device installed on Stephens's car. ${ }^{129}$ Other judges have shared Judge Thacker's belief that GPS technology is fundamentally different from the antiquated beepers of days gone by. ${ }^{130}$ As Chief Judge Alex Kozinski of the Ninth Circuit explained, GPS vehicle trackers "have little in common with the primitive [beeper] devices in Knotts . . . Beepers could help police keep vehicles in view when following them, or find them when they lost sight of them, but they still required at least one officer-and usually many more-to follow the suspect." movements without human intervention-quietly, invisibly, with uncanny precision." 132

Second, Judge Thacker criticized the majority for treating Davis as though it allowed officers to rely on a generalized "vast majority of decisions" from other jurisdictions instead of binding appellate precedent from the governing circuit. ${ }^{133}$ By her reading of Davis, mere reliance on "widely accepted legal norms is not the standard, nor should it be."134 Thus, it did not matter to Judge Thacker what other courts had held. The only thing that mattered was the absence of any Fourth Circuit or Supreme Court precedent directly on-point. ${ }^{135}$

Third, Judge Thacker argued that the deterrence rationale would have been served by applying the exclusionary rule. She emphasized that the officer's conduct occurred after the D.C. Circuit had ruled it unconstitutional to install and monitor GPS vehicle trackers without a warrant; thus, she asserted that the law in the other circuits was unclear at the time the GPS device was

\footnotetext{
129 Id. at $342 \&$ n. 4.

130 See United States v. Katzin, 769 F.3d 163, 193 (3d Cir. 2014) (en banc) (Greenaway, J., dissenting) ("GPS technology is vastly different from the more primitive tracking devices of yesteryear-"beepers."'), cert. denied, 135 S. Ct. 1448 (2015); see also United States v. PinedaMoreno, 617 F.3d 1120, 1124 (9th Cir. 2010) (Kozinski, J., dissenting from denial of rehearing en banc) ("The electronic tracking devices used by the police in this case have little in common with the primitive devices in Knotts.").

131 Pineda-Moreno, 617 F.3d at 1124.

132 Id.; see State v. Adams, 763 S.E.2d 341, 347 n.5 (S.C. 2014) (noting that "beepers serve as aids to law enforcement already conducting physical surveillance, while a GPS enables officers to take a passive role and simply monitor location data from a computer").

133 Stephens, 764 F.3d at 344 (Thacker, J., dissenting).

$134 \quad I d$.

135 Id. Interestingly, the Supreme Court of South Carolina (located within the Fourth Circuit) agreed with Judge Thacker's position and refused to apply the good-faith exception to the preJones installation and monitoring of a GPS vehicle tracker. See Adams, 763 S.E.2d at 347. According to the Adams court, neither Knotts nor Karo "expressly or impliedly authorized" the installation of a GPS device. Id. And, the court further concluded that "no pre-Jones precedent in this federal circuit extended Knotts or Karo to the installation and monitoring of a GPS device." Id.
} 
installed. ${ }^{136}$ In such a circumstance, Judge Thacker believed officers should be encouraged (via the exclusionary rule) to "err on the side of the Constitution and obtain a warrant." 137 At least one Supreme Court Justice would share Judge Thacker's position-Justice Sotomayor made clear in her Davis concurrence that the good-faith exception should not apply when the law in a particular area is in flux. ${ }^{138}$

\section{ANALYSIS OF THE "KNOTTS IS BINDING PRECEDENT UNDER DAVIS" APPROACH}

The Fourth Circuit's decision in Stephens is undoubtedly important for what it held --that Knotts constitutes binding appellate precedent under Davis. But it is perhaps even more important for what it almost (and should have) held. Reading the Stephens majority opinion is a bit like watching a movie where you think you know what is going to happen next, but then all of a sudden there is an unforeseen plot twist. And not just an unforeseen twist, but a twist that is inconsistent with events that previously occurred.

At the beginning of its legal analysis, the majority stated that neither the Supreme Court nor the Fourth Circuit had "expressly approved or disapproved of warrantless GPS usage in 2011."139 Stephens's argument, of course, was that the absence of such express approval placed the case outside

136 Stephens, 764 F.3d at 345 (Thacker, J., dissenting). Judge Thacker was referring to the D.C. Circuit's 2010 decision in United States v. Maynard, 615 F.3d 544 (D.C. Cir. 2010). In Maynard (which became entitled United States $v$. Jones when it reached the Supreme Court), the D.C. Circuit had concluded that the warrantless installation and monitoring of GPS vehicle trackers constituted a Fourth Amendment search. Id. at 555-56. The D.C. Circuit reached that conclusion by employing a theory known as the "mosaic theory"-meaning what may appear trivial to the uninformed may be greatly important to individuals with a broader view. See $i d$. at 562; see also Orin S. Kerr, The Mosaic Theory of the Fourth Amendment, $111 \mathrm{MICH}$. L. REV. 311 , 313 (2012) (stating that Maynard was based on 'a 'mosaic theory' of the Fourth Amendment" and explaining how theory was applied by the D.C. Circuit). The Supreme Court in Jones reached the same result as the D.C. Circuit in Maynard (i.e., treating the installation and monitoring of a GPS vehicle tracker as a "search"), but Jones did not adopt the mosaic theory. See Kerr, supra, at 326 ("Having resolved the case on trespass grounds, Justice Scalia [writing for the majority] did not need to reach the mosaic theory adopted in the D.C. Circuit."). Id.

Stephens, 764 F.3d at 346 (Thacker, J., dissenting).

138 See Davis v. United States, 131 S. Ct. 2419, 2435 (2011) (Sotomayor, J., concurring) ("This case does not present the markedly different question whether the exclusionary rule applies when the law governing the constitutionality of a particular search is unsettled."). Other circuit court judges have expressed the same sentiment as Judge Thacker. See, e.g., United States v. Katzin, 769 F.3d 163, 192 (3d Cir. 2014) (Greenaway, J., dissenting) ("Where an officer decides to take the Fourth Amendment inquiry into his own hands, rather than to seek a warrant from a neutral magistrate-particularly where the law is as far from settled as it was here--he acts in a constitutionally reckless fashion."), cert. denied, 135 S. Ct. 1448 (2015).

Stephens, 764 F.3d at 332 (majority opinion). 
the scope of Davis's holding. ${ }^{140}$ The majority appeared poised to hold that the good-faith exception applied even in the absence of binding precedent. ${ }^{141}$ Indeed, the court expressed its skepticism of the defendant's "narrow view of the good-faith inquiry,"142 and it noted that accepting the narrow view would mean an officer could not rely on "universal, but non-binding, precedent that was directly on point." 143 Furthermore, the court pointed out that the good-faith exception "is not limited to the specific circumstances addressed by the Supreme Court." 144 The scene had been set for the court to take the next step and hold that even though there was no binding appellate precedent in the Fourth Circuit, a reasonable officer would not have known it was illegal to install and monitor a GPS vehicle tracker on public roadways. Then, out of nowhere, the Stephens court punted on that "interesting issue" and held instead that the case fit neatly within the scope of Davis because Knotts was binding appellate precedent that specifically authorized the officer's conduct. ${ }^{145}$

The Fourth Circuit has company at the table for its view of the interplay between Knotts and Davis. The First, Second, Third, and Seventh Circuits $^{146}$-along with several state courts ${ }^{147}$ - have reached the same result.

$\begin{array}{ll}140 & I d . \text { at } 336-37 . \\ 141 & I d . \text { at } 337 . \\ 142 & I d . \\ 143 & I d . \text { at } 337 \mathrm{n} .11 . \\ 144 & I d . \text { at } 336 . \\ 145 & I d . \text { at } 337 .\end{array}$

146 See United States v. Katzin, 769 F.3d 163, 175-76 (3d Cir. 2014) (en banc), cert. denied, 135 S. Ct. 1448 (2015); United States v. Brown, 744 F.3d 474, 478 (7th Cir. 2014); United States v. Aguiar, 737 F.3d 251, 261-62 (2d Cir. 2013) (treating Knotts as binding appellate court precedent for purposes of Davis); United States v. Sparks, 711 F.3d 58, 65 (1st Cir. 2013) (determining that Knotts and a prior First Circuit case applying Knotts were "sufficiently clear and apposite to trigger Davis"). Several other circuits have applied Davis based on the existence of their own circuit precedent regarding precursor technologies to GPS devices. See United States v. Andres, 703 F.3d 828, 835 (5th Cir. 2013) (holding that prior circuit decision authorizing the warrantless monitoring of beepers was binding appellate court precedent under Davis for purposes of warrantless GPS monitoring); see also United States v. Fisher, 745 F.3d 200, 204 (6th Cir. 2014) (holding that a prior circuit decision involving cell-site location information constituted binding precedent authorizing warrantless installation and monitoring of GPS vehicle trackers); United States v. Smith, 741 F.3d 1211, 1221-22 (11th Cir. 2013).

147 See, e.g., Kelly v. State, 82 A.3d 205, 215-16 (Md. 2013) ("We therefore hold that, before Jones, binding appellate precedent in Maryland, namely Knotts, authorized the GPS tracking of a vehicle on public roads."); State v. Johnson, 22 N.E.3d 1061, 1062 (Ohio 2014) (holding that "Knotts and Karo served as binding appellate precedent to justify placing GPS tracking devices on suspects' vehicles without obtaining a search warrant'). Notably, the Supreme Court of South Carolina has issued a decision that squarely contradicts the Fourth Circuit's decision in Stephens. See State v. Adams, 763 S.E.2d 341, 347 (S.C. 2014). The Adams court suppressed the evidence obtained from a GPS vehicle tracker and refused to apply the good-faith exception because there was no binding appellate precedent "in this federal circuit" authorizing warrantless installation 
Although those courts and the Stephens court reached the right result (i.e., refusal to apply the exclusionary rule), they made a misstep by trying to cram the square peg that is Knotts into Davis's round hole. There was a much cleaner way of reaching the same result. The Stephens court should have done what it initially seemed poised to do-hold that at the time the GPS vehicle tracker was installed and monitored no "reasonably well trained officer would have known that the [conduct] was illegal." 148 Instead, the Fourth Circuit (and those courts that have taken the same approach) has distorted Knotts and stretched Davis to create binding appellate precedent where none existed. As explained below in Part III.A, Knotts does not constitute binding appellate precedent under Davis. And Part III.B argues that instead of distorting existing case law to reach a desired result, the courts should have resolved the exclusionary rule question by applying the general good-faith analysis.

\section{A. Knotts Does Not Constitute Binding Appellate Precedent}

In the pre-Jones era, Knotts could have reasonably been read to suggest that a warrant was not needed to install and subsequently monitor a GPS vehicle tracker on public roadways. ${ }^{149}$ A suggestion, however, is not what Davis requires. Rather, Davis is a narrow opinion that was intended to address the very distinct situation of an officer engaging in conduct that was "specifically authorize[d]" by "binding precedent that [was] later overruled."150 Given that the words "specifically authorized" and "binding" appear throughout the Davis opinion, ${ }^{151}$ it is easy to conclude that the Court was serious about its opinion only applying where there was prior "binding precedent" that "specifically authorized" the challenged police conduct.

To put it in terms familiar to any law student, Davis only applies when the prior precedent was a published opinion from the governing circuit court (or

and monitoring of GPS vehicle trackers. Id. According to the court, "Knotts and Karo did not constitute binding precedent" because neither case "expressly or impliedly authorized, a physical trespass as occurred in this case." Id.

148 Herring v. United States, 555 U.S. 135, 145 (2009).

149 See generally Fisher, 745 F.3d at 204 (stating that Knotts and Karo, when read together, "strongly suggested" but did not go so far as to specifically authorize the warrantless installation and monitoring of GPS devices).

150 See Davis v. United States, 131 S. Ct. 2419, 2423, 2429 (2011); see also People v. LeFlore, 32 N.E.3d 1043, 1070, 1074 (Ill. 2015) (Burke, J., dissenting) (arguing that "Davis recognized a narrow exception" that applies only when "there exists binding precedent within the particular jurisdiction governing the law enforcement officials"); State v. Hohn, 321 P.3d 799 (Kan. Ct. App. 2014) (unpublished table decision) (explaining that adopting the prosecution's interpretation of Davis "would be to extend the definition of binding precedent way beyond its original boundaries"); Mason, supra note 4, at 69-72 (arguing that Davis is a narrow opinion that does not apply unless there is binding precedent that "expressly authorized the search").

151 See, e.g., Davis, 131 S. Ct. at 2423-24, 2428-29. 
the Supreme Court) that is "on all fours" with the current case. Returning to the example case of Stephens, there was no Supreme Court or Fourth Circuit precedent specifically authorizing the warrantless installation and monitoring of GPS vehicle trackers prior to Jones. Rather than acknowledging the absence of binding precedent and deciding the case without reliance on Davis, the Fourth Circuit and many of its sister circuits have mistakenly chosen to pretend that Knotts was binding precedent that specifically authorized the warrantless installation and monitoring of GPS vehicle trackers. ${ }^{152}$

A close reading of Knotts, however, shows that the Court's decision only addressed the act of monitoring a vehicle's location using a tracking device. It said nothing about the installation of a tracking device on an individual's vehicle. ${ }^{153}$ In the second beeper case, Karo, the Court briefly addressed whether installing the beeper in a container implicated the Fourth Amendment. ${ }^{154}$ The Karo Court concluded that the installation of the beeper (with permission from the owner of the container where the beeper was placed) was insufficient to trigger the Fourth Amendment. ${ }^{155}$ Thus, to arrive at the conclusion that the installation and monitoring of a GPS vehicle tracker was not a search prior to Jones, one would have to read Knotts and Karo, extrapolate general principles from them, combine those general principles together, and then apply those general principles to GPS vehicle trackers through analogical reasoning. ${ }^{156}$ That is a far cry from Davis, where there was a binding appellate court decision holding " $\mathrm{X}$ is constitutional" and an officer performed " $\mathrm{X}$."

152 See United States v. Katzin, 769 F.3d 163, 175-76 (3d Cir. 2014) (en banc), cert. denied, 135 S. Ct. 1448 (2015); United States v. Stephens, 764 F.3d 327, 337 (4th Cir. 2014) (stating that the officer's "use of the GPS was objectively reasonable because of the binding appellate precedent of Knotts"), cert. denied, 2015 WL 1970174 (U.S. Oct. 5, 2015) (No. 14-1313); United States v. Brown, 744 F.3d 474, 478 (7th Cir. 2014); United States v. Sparks, 711 F.3d 58, 65 (1st Cir. 2013) (determining that Knotts and a prior First Circuit case applying Knotts were "sufficiently clear and apposite to trigger Davis"); United States v. Aguiar, 737 F.3d 251, 261-62 (2d Cir. 2013) (treating Knotts as binding appellate court precedent for purposes of Davis).

153 See Mason, supra note 4, at 78 (recognizing that neither Knotts nor Karo "expressly authorize the non-consensual installation of a tracker").

154 See United States v. Karo, 468 U.S. 705, 712-13 (1984). The Court viewed the installation of the beeper as a "technical trespass" that "was only marginally relevant to the question of whether the Fourth Amendment has been violated." Id. According to the Karo Court, a physical trespass was "neither necessary nor sufficient to establish a constitutional violation." Id. at 713.

155 See id. (concluding "that no Fourth Amendment interest of Karo or of any other respondent was infringed by the installation of the beeper").

156 See Mason, supra note 4, at 78 (explaining that "Davis is about express authorization (rather than the possibility of creative analogizing)"); see also Katzin, 769 F.3d at 188 (Greenaway, J., dissenting) (criticizing the majority for holding that "two disparate Supreme Court precedents [Knotts and Karo]" can be read together to constitute binding appellate precedent for purposes of Davis). 
Additionally, beepers and GPS devices (while sharing some similarities) are not synonymous. ${ }^{157} \mathrm{~A}$ beeper "is a radio transmitter, usually battery operated, which emits periodic signals that can be picked up by a radio receiver." 158 Beepers require active involvement by a police officer on the street because they only work if an officer with a radio receiver is physically close enough to the beeper to pick up the signal it emits. ${ }^{159}$ Beepers also lack the ability to provide location information with pinpoint precision. ${ }^{160}$ GPS devices, on the other hand, are much more precise, require fewer resources, and store significantly more data. ${ }^{161}$ Indeed, some modern GPS devices can determine location "with accuracy to within ten inches." 162 And, GPS devices can store " 8,000 to 17,000 data points" per day ${ }^{163}$ all with very little active involvement required on the part of law enforcement officers. ${ }^{164}$

To be blunt, treating a case about beepers as though it was binding precedent in a case about GPS devices is akin to treating a case about horses as

See Stephens, 764 F.3d at 342 n.4 (Thacker, J., dissenting) (noting that a beeper and a GPS device "are of an entirely different character. A beeper ... requires law enforcement to at least be in proximity to the device to receive the transmitted signal, whereas a GPS device downloads location data at specific time intervals with no proximity needed."); see also Katzin, 769 F.3d at 193 (Greenaway, J., dissenting) ("GPS technology is vastly different from the more primitive tracking devices of yesteryear-'beepers."'); United States v. Pineda-Moreno, 617 F.3d 1120 , 1124 (9th Cir. 2010) (Kozinski, J., dissenting from denial of rehearing en banc) ("The electronic tracking devices used by the police in this case have little in common with the primitive devices in Knotts.").

158 Jordan Miller, New Age Tracking Technologies in the Post-United States v. Jones Environment: The Need for Model Legislation, 48 CREIGHTON L. REv. 553, 557 (2015).

$159 I d$. at 558 (explaining that the "beeper's reliability and range vary, with a typical groundto-ground signal in an uninhabited area of two to four miles," and in more urban areas with an increased likelihood of interference, "the receiver's efficacy may be limited to an area within a two-block radius of the beeper").

160 Id. ("Beeper devices lack the capacity to triangulate an individual's location with pinpoint accuracy, instead only offering more generalized locational data.").

161 See United States v. Jones, 132 S. Ct. 945, 963-64 (2012) (Alito, J., concurring) (discussing the capabilities of GPS technology); see also Courtney Elgart, Note, The Road from Jones: The Requirement of Reasonableness for a GPS Search of a Vehicle, 52 AM. CRIM. L. REV. 631,643 (2015) ("GPS uses satellites to determine the location of a receiver, including latitude, longitude, altitude, speed, and direction. A GPS device can calculate its location to within a few centimeters and usually recalculates its location over five to ten second intervals.").

162 See Miller, supra note 158 , at 561.

163 Elgart, supra note 161, at 631 (“A Global Positioning System ('GPS') device records its location every five to ten seconds. Over the course of one day, a GPS device could produce approximately 8,000 to 17,000 data points. Those data points include the device's latitude, longitude, altitude, and a time stamp.").

164 See Miller, supra note 158, at 561-62 (explaining that GPS devices provide "the secondary advantage of allowing law enforcement to not allocate personnel to constant roundthe-clock monitoring while allowing them to gain the same information on the movements of the individual/object tracked"). 
binding precedent in a case about automobiles. There are similarities between the two technologies and they accomplish the same general goal, but they are not the same. Such a situation stands in stark contrast to what happened in Davis. The officer in Davis searched a car incident to the lawful arrest of a recent occupant, and he followed "to the letter" an Eleventh Circuit decision involving a virtually identical fact pattern. ${ }^{165}$ The fact patterns were the same, and the legal questions were identical. ${ }^{166}$

Finally, and perhaps most importantly, the Supreme Court declared in Jones that neither Knotts nor Karo authorized the warrantless installation and monitoring of GPS vehicle trackers. ${ }^{167}$ According to the Court, the Jones decision is "perfectly consistent" with Knotts and Karo because those cases did not involve the trespassory installation of a tracking device without the consent of the owner. ${ }^{168}$ Thus, the Court's decision in Jones left both Knotts and Karo intact. Put another way, the Supreme Court has made clear that neither Knotts nor Karo authorized officers to install and monitor GPS vehicle trackers without a warrant. It is, therefore, virtually beyond the realm of possibility to believe that the Supreme Court would view Knotts as "binding appellate precedent [that] specifically authorize [d]"169 the installation and monitoring of GPS vehicle trackers.

Clearly, the circuit courts-like the Stephens court-that have adopted the "Knotts is binding precedent under Davis approach" have done so because they cringed at the thought of "set[ting] the criminal loose in the community without punishment"170 because a well-meaning officer failed to predict the Supreme Court's decision in Jones. Their reluctance to apply the exclusionary rule in such a situation is understandable. ${ }^{171}$ But, their approach-squeezing Knotts to fit within Davis-is analytically indefensible and difficult to comprehend. It is made all the more difficult to comprehend by the fact that the

\footnotetext{
165 See Davis v. United States, 131 S. Ct. 2419, 2428 (2011).

166 Id. (explaining that the search of Davis's car incident to his arrest followed then-existing Eleventh Circuit precedent "to the letter").

167 See United States v. Jones, 132 S. Ct. 945, 951-52 (2012).

168 See id. at 952 (explaining that Knotts did not involve a challenge to the installation of the beeper and Karo addressed the "specific question" of whether installation of the device "with the consent of the original owner" of the container where the beeper was placed implicated the Fourth Amendment); see also United States v. Stephens, 764 F.3d 327, 343 (4th Cir. 2014) (Thacker, J., dissenting) ("Indeed, the Supreme Court's discussion in Jones . . of its own beeper cases forecloses the possibility that these cases support the warrantless GPS search in the case at hand."), cert. denied, 2015 WL 1970174 (U.S. Oct. 5, 2015) (No. 14-1313); State v. Mitchell, 323 P.3d 69, 78 (Ariz. Ct. App. 2014).
}

169 Davis, 131 S. Ct. at 2429.

170 See id. at 2427.

171 See id. (explaining the downsides of applying the exclusionary rule). 
court in Stephens and its sister circuits could have taken another, much less rocky, path to the same result.

\section{B. A Better Path Leading to the Same Result}

The decisions of those courts that have adopted the "Knotts is binding precedent under Davis approach" would have been more analytically sound (but no less controversial) had they resolved the exclusionary rule issue without relying on Davis. Generally speaking, to determine whether the good-faith exception to the exclusionary rule applies, courts must determine "whether a reasonably well trained officer would have known that the search was illegal in light of all the circumstances."172 If the answer is "no," then the exclusionary rule is inapplicable. The good-faith inquiry is reflective of the Supreme Court's current view of the exclusionary rule as the nuclear option that only applies when there is "deliberate, reckless, or grossly negligent conduct, or in some circumstances recurring or systemic negligence" by the police. ${ }^{173}$

The Supreme Court's decision in Davis is only one example of a circumstance where an officer would not have known his conduct was illegal. ${ }^{174}$ But other circumstances exist-circumstances not quite as clear as those presented in Davis - where the good-faith exception also should apply. As the Third Circuit has explained, "[e]ven where Davis does not control, it is our duty to consider the totality of the circumstances to answer the 'objectively ascertainable question' of whether a reasonable police officer would have known the search was illegal." ${ }^{175}$ Rather than devoting so much energy to unconvincingly explaining why Knotts was binding appellate precedent, the circuit courts should have simply answered the general good-faith question of whether on May 31, 2011, a reasonable officer would have known it was unlawful to install and monitor a GPS vehicle tracker on public roadways without a warrant. Considering the legal landscape prior to Jones, there is a strong argument that the question should have been answered "no.",

\footnotetext{
172 Herring v. United States, 555 U.S. 135, 145 (2009)

173 Id. at 144.
}

174 See People v. LeFlore, 32 N.E.3d 1043, 1050 (Ill. 2015) (explaining that "application of the good-faith inquiry is not limited to the specific circumstances addressed by the Supreme Court in Davis").

175 United States v. Katzin, 769 F.3d 163, 177 (3d Cir. 2014) (en banc) (quoting United States v. Leon, 468 U.S. 897, 906-07, 922 n.23 (1984)), cert. denied, 135 S. Ct. 1448 (2015); see also LeFlore, 32 N.E.3d at 1057 (agreeing with Katzin that even if Knotts was not binding precedent under Davis the exclusionary rule would be inapplicable under the "Supreme Court's general good-faith analysis" because the officer "in relying on the legal landscape that existed at the time the search was conducted" did not act unreasonably or with the required level of culpability).

176 See generally United States v. Brown, 744 F.3d 474, 478 (7th Cir. 2014) ("One can doubt that much deterrence is to be had from telling the police that they are not entitled to rely on 
Looking specifically at the facts of Stephens, it should be remembered that when the officer (a local Maryland police officer working on a federal taskforce) installed the GPS vehicle tracker on Stephens's car, there was Maryland state court precedent authorizing his conduct. ${ }^{177}$ Moreover, from the officer's past experience with GPS vehicle trackers, he had no reason to believe a warrant was required. ${ }^{178}$ In fact, as the district court judge remarked, if the officer had sought a warrant the magistrate judge likely would have said "you don't need a warrant for that."179 The United States Department of Justice shared the same view. ${ }^{180}$ So too did the Fourth Circuit's sister circuits (save one) who had addressed the issue of GPS vehicle trackers prior to Jones. ${ }^{181}$ And while out-of-circuit decisions are not binding, it is commonplace and certainly not unreasonable for officers-like lawyers and judges--to rely on out-of-circuit precedent when the governing circuit has yet to confront a particular problem. ${ }^{182}$ Expecting more of police officers than of Article III judges, state court judges, and federal prosecutors is fundamentally unfair. ${ }^{183}$

decisions issued by several circuits, just because the circuit covering the state in which an investigation is ongoing lacks its own precedent.").

177 See United States v. Stephens, 764 F.3d 327, 334 (4th Cir. 2014) (citing case law from the Maryland Court of Special Appeals), cert. denied, 2015 WL 1970174 (U.S. Oct. 5, 2015) (No. 14-1313). The question of whether a state court precedent qualifies as binding appellate precedent for a state police officer who is working on a federal investigation is beyond the scope of this Article. Professor Caleb Mason, however, has written an article that discusses that issue and many others. See Mason, supra note 4, at 72-78.

178 See Stephens, 764 F.3d at 331 (describing the officer's experience with GPS vehicle trackers and his understanding of the law at the time the device was installed on Stephens's car).

179 See id.

180 See Katzin, 769 F.3d at 181 ("'II]t was DOJ policy at the time that a warrant was not required to install a battery-powered GPS on a vehicle parked on a public street and to surveil it on public roads.").

181 See id. at 180 (stating that prior to Jones there "was a nearly uniform consensus across the federal courts of appeals that addressed the issue that the installation and subsequent use of a GPS or GPS-like device was not a search, or, at most, was a search but did not require a warrant... The lone dissenting voice was United States v. Maynard, 615 F.3d 544 (D.C. Cir. 2010).").

182 See United States v. Brown, 744 F.3d 474, 478 (7th Cir. 2014) ("One can doubt that much deterrence is to be had from telling the police that they are not entitled to rely on decisions issued by several circuits, just because the circuit covering the state in which an investigation is ongoing lacks its own precedent.").

183 Interestingly, Justice Breyer's dissenting opinion recognized the difficulty of saying that an officer who relies in good faith on non-binding precedent (in the absence of binding precedent) is any more culpable than an officer who relies in good faith on binding precedent. See Davis v. United States, 131 S. Ct. 2419, 2439 (2011) (Breyer, J., dissenting) ("But an officer who conducts a search that he believes.complies with the Constitution but which, it ultimately turns out, falls just outside the Fourth Amendment's bounds is no more culpable than an officer who follows erroneous 'binding precedent.' Nor is an officer more culpable where circuit 
If the Supreme Court means what it has said, then the exclusionary rule only applies when officers have violated a defendant's rights deliberately, recklessly, or through gross or systemic negligence. ${ }^{184}$ None of those labels fit the conduct of officers like the officer in Stephens who reasonably believed that he was acting lawfully. Thus, the circuit courts should have refused to apply the exclusionary rule in cases like Stephens because no "reasonably well trained officer would have known that ... [it] was illegal" 185 to install and monitor a GPS vehicle tracker on public roadways before Jones. After all, how could an officer be viewed as violating a defendant's rights deliberately, recklessly, or through gross negligence when the officer's actions were consistent with (1) the vast majority of persuasive federal precedent, ${ }^{186}$ (2) precedent from numerous state courts, ${ }^{187}$ and (3) the legal advice espoused by the highlytrained lawyers at the United States Department of Justice? ${ }^{188}$

Instead of taking that straightforward approach, there is now circuit precedent nationwide standing for the proposition that "binding appellate precedent" actually means "persuasive precedent" and "specifically authorizing" actually means "suggesting." Aside from contradicting the express language of Davis's holding, this approach obscures the true nature of the modern exclusionary rule inquiry. By going to such lengths to fit GPS vehicle trackers within the holding of Knotts, the circuit courts in decisions like Stephens have made it (incorrectly) appear that Davis is itself a separate exception rather than one example of a circumstance where a reasonably well trained police officer would not have known his or her conduct was illegal. ${ }^{189}$

precedent is simply suggestive rather than 'binding,' where it only describes how to treat roughly analogous instances, or where it just does not exist.").

184 See Herring v. United States, 555 U.S. 135, 147-48 (2009) (stating that "when police mistakes are the result of negligence... , rather than systemic error or reckless disregard of constitutional requirements, any marginal deterrence does not 'pay its way.' In such a case, the criminal should not go free because the constable has blundered." (quoting United States v. Leon, 468 U.S. 897, 907 n.6 (1984))).

185 Id. at 145.

186 See, e.g., United States v. Robinson, 781 F.3d 453 (8th Cir. 2015); Brown, 744 F.3d at 474; United States v. Fisher, 745 F.3d 200 (6th Cir. 2014); United States v. Katzin, 769 F.3d 163 (3d Cir. 2014) (en banc), cert. denied, 135 S. Ct. 1448 (2015); United States v. Aguiar, 737 F.3d 251 (2d Cir. 2013); United States v. Andres, 703 F.3d 828 (5th Cir. 2013); United States v. Barraza-Maldonado, 732 F.3d 865 (8th Cir. 2013); United States v. Sparks, 711 F.3d 58 (1st Cir. 2013); United States v. Pineda-Moreno, 688 F.3d 1087 (9th Cir. 2012).

187 See, e.g., Stone v. State, 941 A.2d 1238 (Md. Ct. Spec. App. 2008), abrogated by Kelly v. State, 56 A.2d 523 (Md. Ct. Spec. App. 2012).

188 See Katzin, 769 F.3d at 181 (reporting that prior to Jones, the Department of Justice policy was "that a warrant was not required to install a battery-powered GPS on a vehicle parked on a public street and to surveil it on public roads").

189 The Third Circuit primarily held that the Supreme Court's decisions in Knotts and Karo "were binding appellate precedent upon which the agents could reasonably have relied under Davis." Id. at 173 . The court, however, did conclude "[i]n the altemative we conclude that, under 
As explained in the next Part of this Article, the scope of Davis and its place in the overall exclusionary rule scheme is an issue that will continue to face the courts.

\section{The NeXt WaVe of Litigation Regarding THE SCOPE OF DaVIS'S HOLDING}

Over two years have passed since Jones declared the installation and monitoring of a GPS vehicle tracker to be a Fourth Amendment "search." As discussed in the preceding sections, those two years have been filled with litigation over the fate of evidence gathered from GPS vehicle trackers installed and monitored pre-Jones. Given that most circuit courts have now addressed that question, new cases raising that precise issue will be few. But, Stephens and the other cases that have endorsed the "Knotts is binding precedent under Davis approach" will remain important. That is so because the question of Davis's meaning - and the broader question about the applicability of the exclusionary rule in cases where new technology leads to the upheaval of settled Fourth Amendment expectations-is not going away. Indeed, the next wave of litigation raising those issues has already formed.

That wave of litigation involves the Supreme Court's recent landmark decision in Riley $v$. California. ${ }^{190}$ At issue in Riley was the applicability of the search incident to lawful arrest doctrine to cell phones found on a person who had been arrested. ${ }^{191}$ Under the search incident to lawful arrest doctrine that was first announced in Chimel $v$. California, ${ }^{192}$ officers who have made a lawful arrest may, without a warrant, search the arrestee's person and the area within the arrestee's immediate control. ${ }^{193}$ In a series of cases following Chimel, the Court held that the search incident to lawful arrest doctrine also authorizes the police to search containers" 194 and other items of "personal

the Supreme Court's more general good faith test, the evidence should not be suppressed because the agents acted with a good faith belief in the lawfulness of their conduct that was objectively reasonable." Id.; see also People v. LeFlore, 32 N.E.3d 1043, 1057 (Ill. 2015) (following the approach taken by the Third Circuit in Katzin). The Third Circuit's alternative holding is the approach this Article argues should have been the primary approach taken by all of the circuits.

190134 S. Ct. 2473, 2480 (2014).

191 See id. (stating the question presented as "whether the police may, without a warrant, search digital information on a cell phone seized from an individual who has been arrested").

192395 U.S. 752, 762-63 (1969), abrogated by Davis v. United States, 131 S. Ct. 2419 (2011).

193 See id. at 763 ("There is ample justification, therefore, for a search of the arrestee's person and the area "within his immediate control'-construing that phrase to mean the area from within which he might gain possession of a weapon or destructible evidence.").

194 See United States v. Robinson, 414 U.S. 218, 236 (1973) (holding that the search incident to lawful arrest doctrine authorized a police officer to conduct a warrantless search of a cigarette pack that was found on the defendant's person after his arrest). 
property ... immediately associated with the person of the arrestee."195 Thus, prior to Riley, the search incident to lawful arrest doctrine provided officers with near carte blanche authority to search every item found on an arrestee's person or within the arrestee's grabbing area, so long as the search was contemporaneous with the arrest. ${ }^{196}$

As the prevalence of cell phones increased, police officers were frequently finding them on arrestees. ${ }^{197}$ And, that raised the following question in courts nationwide: Is a warrant required to search the contents of the cell phone, or may the police conduct such a search under the search incident to lawful arrest doctrine? ${ }^{198}$ The lower courts were divided on the answer, but the majority view was that the search incident to lawful arrest doctrine authorized warrantless searches of cell phones found on an arrestee's person at the time of arrest. ${ }^{199}$ Those courts generally viewed cell phones as containers-and there was a bright-line rule that containers found on the person of an arrestee were subject to search under the search incident to lawful arrest doctrine. ${ }^{200}$

See United States v. Chadwick, 433 U.S. 1, 15 (1977) (holding that the search incident to lawful arrest doctrine did not authorize a warrantless search of a 200-pound footlocker that was in the defendant's trunk when he was arrested), abrogated by California v. Acevedo, 500 U.S. 565 (1991).

196 See Wayne A. Logan, An Exception Swallows a Rule: Police Authority to Search Incident to Arrest, 19 Y ALE L. \& POL'Y REV. 381, 381 (2001) (stating that the search incident to lawful arrest doctrine "affords police an unqualified right to search anyone they arrest, without first obtaining a search warrant from a neutral judicial official'); see also Adam M. Gershowitz, The iPhone Meets the Fourth Amendment, 56 UCLA L. REv. 27, 30-31 (2008) (stating that "the search incident to [lawful] arrest doctrine has functioned as a bright-line rule-allowing police to search the entire person of an arrestee without getting into sticky questions of whether there was probable cause to open a particular container").

197 See Gershowitz, supra note 196, at 29 (discussing the prevalence of cell phones in American society); see also Riley v. California, 134 S. Ct. 2473, 2484 (2014) (stating that cell phones "are now such a pervasive and insistent part of daily life that the proverbial visitor from Mars might conclude they were an important feature of human anatomy").

198 See Margaret M. Lawton, Warrantless Searches and Smartphones: Privacy in the Palm of Your Hand?, 16 UDC/DCSL L. REV. 89, 89 (2012) (explaining that the question of whether cell phones may be searched incident to lawful arrest was one facing courts across the country).

199 See United States v. Trapp, No. 1:13-cr-62, 2014 WL 1117012, at *12 (D. Vt. Mar. 20, 2014) (stating that "at the time of the search, 'all of the circuits to address the issue had permitted' cell phone searches incident to arrest" (quoting United States v. Mayo, No. 2:13-CR48, 2013 WL 5945802, at *15 (D. Vt. Nov. 6, 2013))); see also Gracie v. State, 92 So. 3d 806, 812 (Ala. Crim. App. 2011) ("We agree with the majority of jurisdictions surveyed that a warrantless search of a defendant's cellular telephone following his arrest does not violate Fourth Amendment principles ...."); Lawton, supra note 198, at 89 (explaining that "the vast majority of courts, both state and federal, to have considered the issue have allowed warrantless searches of cell phones").

200 See Lawton, supra note 198, at 104-05 ("Most courts, both federal and state, that have considered searches of cell phones incident to arrest have treated those devices as containers, drawing analogies between cell phones and address books, or pagers, for example."); see also 
That bright-line rule became much dimmer on June 25, 2014, when the Court issued its decision in Riley. The Riley Court narrowed the scope of the search incident to lawful arrest doctrine by holding that, absent exigent circumstances, officers must have a warrant to "search digital information on a cell phone seized from an individual who has been arrested." ${ }^{201}$ Due largely to their "immense storage capacity," the Court distinguished cell phones from other containers that cannot store nearly as much private information. ${ }^{202}$

The issue now being litigated in the lower courts is whether the exclusionary rule applies to evidence obtained via warrantless searches of cell phones conducted incident to lawful arrest before Riley. ${ }^{203}$ Building on its success in having the lower courts refuse to exclude evidence obtained from GPS vehicle trackers installed and monitored pre-Jones, the government has been pushing the courts to apply Davis to the pre-Riley cell phone search cases. ${ }^{204}$ Thus, to determine whether the exclusionary rule applies to pre-Riley

Gershowitz, supra note 196, at 31 ("Thus, if we think of an iPhone as a container-like a cigarette package or a closed box-police can open and search the contents inside with no questions asked and no probable cause required, so long as they are doing so pursuant to a valid arrest.").

201 Riley, 134 S. Ct. at 2477.

202 See id. at 2489 ("Cell phones differ in both a quantitative and qualitative sense from other objects that might be kept on an arrestee's person... Before cell phones, a search of a person was limited by physical realities and tended as a general matter to constitute only a narrow intrusion of privacy.").

203 See, e.g., United States v. Gary, 790 F.3d 704, 705 (7th Cir. 2015) (applying Davis and affirming denial of motion to suppress evidence obtained from a cell phone search conducted without a warrant before Riley); United States v. Clark, 29 F. Supp. 3d 1131, 1135-36 (E.D. Tenn. 2014) (refusing to apply the exclusionary rule to a pre-Riley search of a cell phone even though there was no Sixth Circuit precedent specifically authorizing the search, and reading Davis broadly to encompass the Supreme Court's decision in Robinson which upheld the search incident to lawful arrest of a container found on the defendant's person); United States v. Jenkins, No. 3:13-cr-30125-DRH-11, 2014 WL 4470609, at *1 (S.D. Ill. Sept. 10, 2014) (applying Davis and refusing to apply the exclusionary rule to a pre-Riley cell phone search, even though there was no Seventh Circuit precedent specifically authorizing cell phone searches incident to a lawful arrest); Spence v. State, 118 A.3d 864, 867-68 (Md. Ct. App. 2015) (applying Davis and concluding that the Supreme Court's decision in Robinson constituted binding precedent on the issue of cell phone searches prior to Riley); Trapp, 2014 WL 1117012, at *12 (citing Davis and concluding that the good-faith exception to a pre-Riley search of a cell phone incident to lawful arrest). But see United States v. Eisenhour, 44 F. Supp. 3d 1028, 1032 (D. Nev. 2014) (refusing to apply the good-faith exception to a pre-Riley cell phone search because there was no "binding appellate precedent in this case for the police to rely upon. No Ninth Circuit case explicitly rules that digital data on a cell phone can be searched incident to arrest.").

204 See, e.g., Clark, 29 F. Supp. 3d at 1145 ("The government contends the exclusionary rule should not apply here because Officer Narramore engaged in a limited search of the smartphone at the scene of arrest and during the interview under a good faith assumption that no warrant was necessary."). 
searches of cell phones incident to lawful arrest, the courts are plowing the same ground they plowed in the post-Jones GPS vehicle tracker cases.

Three circuits had explicitly held in pre-Riley published opinions that warrantless searches of cell phones incident to arrest were authorized by the Fourth Amendment. ${ }^{205}$ In those circuits, Davis clearly applies because the officers were relying on "binding precedent that [was] later overruled." 206 And, one circuit - the First Circuit-had explicitly held pre-Riley that cell phones could not be searched incident to lawful arrest without a warrant. ${ }^{207}$ It cannot be disputed, therefore, that Davis does not save the evidence obtained from preRiley cell phone searches in the First Circuit. But, what about the circuits that had not specifically addressed searching cell phones incident to lawful arrest before Riley?

Those circuits will be in the same position the Fourth Circuit and many of its sister circuits were in with regard to evidence obtained from GPS vehicle trackers that were installed and monitored before Jones. Relying on the broad reading of Davis embodied by the "Knotts is binding precedent under Davis approach," the government is, unsurprisingly, advancing the argument that the Supreme Court's 1973 decision in United States $v$. Robinson, ${ }^{208}$ regarding the search of a cigarette pack, constituted binding precedent specifically authorizing the search of a cell phone incident to lawful arrest before Riley. ${ }^{209}$ As the argument goes, prior to Riley the lower courts had generally viewed Robinson as standing for the proposition that the police may search incident to lawful arrest any container found on the arrestee's person. ${ }^{210} \mathrm{~A}$ cell phone is a

205

See, e.g., United States v. Murphy, 552 F.3d 405, 411-12 (4th Cir. 2009); United States v. Finley, 477 F.3d 250, 260 (5th Cir. 2007). The Seventh Circuit had upheld a search incident to lawful arrest of a cell phone before Riley, but the court suggested that its opinion was limited to authorizing a search of a cell phone to obtain the phone's number. See United States v. FloresLopez, 670 F.3d 803, 809-10 (7th Cir. 2012) (providing a detailed analysis of the search incident to lawful arrest doctrine in the context of cell phones, but leaving the questions about searching the contents of a cell phone for "another day, since the police [in this case] did not search the contents of the defendant's cell phone, but were content to obtain the cell phone's phone number"). The Eleventh Circuit had issued an unpublished decision upholding the search of a cell phone incident to lawful arrest. See United States v. Fuentes, 368 F. App'x 95, 99 (11th Cir. 2010). The issue of whether unpublished decisions qualify as "binding precedent" under Davis is an interesting question that is beyond the scope of this Article.

206 Davis v. United States, 131 S. Ct. 2419, 2423 (2011).

207 See United States v. Wurie, 728 F.3d 1, 13 (1st Cir. 2013), aff'd sub nom., Riley v. California, 134 S. Ct. 2473 (2014).

208414 U.S. 218 (1973).

209 See United States v. Garcia, 68 F. Supp. 3d 1113, 1120 (N.D. Cal. 2014) (rejecting the government's argument that "the Court should refuse to suppress the cellphone search because the officers searched Defendant's cellphone in reliance on the Supreme Court's 1973 holding that officers may open a cigarette package found on a suspect's person incident to his arrest").

210 See generally Lawton, supra note 198, at 104-05 (pointing out-pre-Riley-that "[m]ost courts ... that have considered searches of cell phones incident to arrest have treated these 
modern-day container. Therefore, Robinson authorized the search incident to lawful arrest of cell phones. So far, the government's argument has gained some traction with one circuit court and several district courts finding it persuasive. ${ }^{211}$

As the issue continues to work its way through the system, courts without any pre-Riley precedent directly addressing searches of cell phones incident to lawful arrest should resist the temptation to employ the reasoning that led to the "Knotts is binding precedent under Davis approach." In other words, the courts should refuse to identify a case (i.e., Robinson) from over forty years ago that shares some basic similarities with the searching of cell phones and pretend that it qualifies under Davis as binding precedent that specifically authorized police officers to search a cell phone-a device that was little more than a pipe dream at the time Robinson was decided. Instead, the courts should simply conduct the general good-faith inquiry by asking and answering the following question: At the time of the search, would a reasonably well trained police officer have known that it was illegal to search a cell phone incident to lawful arrest? The answer to that question may not be easy, but at least it is the right question to ask. Should the courts choose, however, to adopt the same broad reading of Davis that led to the "Knotts is binding precedent under Davis approach," the result will be a continued and unwarranted distortion of Davis's narrow holding. ${ }^{212}$

devices as containers, drawing analogies between cell phones and address books, or pagers"); see also Gershowitz, supra note 196, at 31 (stating pre-Riley that "if we think of an iPhone as a container-like a cigarette pack or a closed box-police can open and search the contents inside with no questions asked and no probable cause required, so long as they are doing so pursuant to a valid arrest").

211 See, e.g., United States v. Gary, 790 F.3d 704, 705, 709-10 (7th Cir. 2015) (treating Robinson and prior circuit court precedent in analogous cases as binding appellate precedent authorizing the search incident to lawful arrest of a cell phone prior to Riley); United States v. Clark, 29 F. Supp. 3d 1131, 1145 (E.D. Tenn. 2014) (concluding that the "Supreme Court authority regarding searches of other types of containers found on an arrestee's person, such as Robinson and its progeny, in combination with the decisions of all circuit courts to have addressed the issue of a cell phone search incident to arrest at the time of the searches of Defendant's smartphone, render the actions of [the officer] objectively reasonable under the reasoning of Davis"); see also United States v. Caldwell, No. 1:13-cr-128, 2015 WL 179583, at *12 (E.D. Tenn. Jan. 14, 2015).

212 See generally People v. LeFlore, 32 N.E.3d 1043, 1070-71 (Ill. 2015) (Burke, J., dissenting) (opining that the broad "legal landscape" interpretation of Davis endorsed by many courts is "directly at odds with Davis" itself which "recognized a narrow exception" that "was limited to jurisdictions which clearly authorized the officer's conduct.... There are no references in Davis to 'generally accepted authority,' 'legal landscape,' or persuasive or wellreasoned precedent.”). 


\section{CONCLUSION}

The Supreme Court's decision in Davis was intended to be a narrow one that, by its terms, only applies when "binding appellate precedent specifically authorize [d] a particular police practice" that was later deemed unconstitutional. ${ }^{213}$ When confronted with a situation where a widespread police practice-the warrantless installation and monitoring of GPS vehicle trackers-was declared unconstitutional by the Court in Jones, the lower courts were forced to determine whether the exclusionary rule applied to evidence obtained from those GPS vehicle trackers. A majority of the circuit courts resolved that issue by applying the "Knotts is binding precedent under Davis approach." That approach required bending, twisting, and distorting Davis to apply in a situation where there was not actually any binding precedent that specifically authorized the officer's conduct. The courts could have (and should have) reached the same end result by applying the general good-faith analysis. Here's hoping that in future cases, like those involving pre-Riley searches of cell phones incident to lawful arrest, the courts will resolve the exclusionary rule issue without further muddying the clear holding of Davis. 